\title{
Hypoxia, partial EMT and collective migration: Emerging culprits in metastasis
}

\author{
Kritika Saxena $^{\text {a }}$, Mohit Kumar Jolly ${ }^{\text {a,* }}$, Kuppusamy Balamurugan ${ }^{\text {b,* }}$ \\ ${ }^{a}$ Centre for BioSystems Science and Engineering, Indian Institute of Science, Bangalore 560012, India \\ b Laboratory of Cell and Developmental Signaling, Center for Cancer Research, National Cancer Institute, Frederick, MD 21702, USA
}

\section{A R T I C L E I N F O}

\section{Article history:}

Received 30 May 2020

Received in revised form 12 July 2020

Accepted 27 July 2020

\section{Keywords:}

HIF-1 $\alpha$

partial EMT

Collective migration

Inflammatory breast cancer

Metastasis

\begin{abstract}
A B S T R A C T
Epithelial-mesenchymal transition (EMT) is a cellular biological process involved in migration of primary cancer cells to secondary sites facilitating metastasis. Besides, EMT also confers properties such as stemness, drug resistance and immune evasion which can aid a successful colonization at the distant site. EMT is not a binary process; recent evidence suggests that cells in partial EMT or hybrid E/M phenotype(s) can have enhanced stemness and drug resistance as compared to those undergoing a complete EMT. Moreover, partial EMT enables collective migration of cells as clusters of circulating tumor cells or emboli, further endorsing that cells in hybrid E/M phenotypes may be the 'fittest' for metastasis. Here, we review mechanisms and implications of hybrid E/M phenotypes, including their reported association with hypoxia. Hypoxia-driven activation of HIF-1 $\alpha$ can drive EMT. In addition, cyclic hypoxia, as compared to acute or chronic hypoxia, shows the highest levels of active HIF-1 $\alpha$ and can augment cancer aggressiveness to a greater extent, including enriching for a partial EMT phenotype. We also discuss how metastasis is influenced by hypoxia, partial EMT and collective cell migration, and call for a better understanding of interconnections among these mechanisms. We discuss the known regulators of hypoxia, hybrid EMT and collective cell migration and highlight the gaps which needs to be filled for connecting these three axes which will increase our understanding of dynamics of metastasis and help control it more effectively.
\end{abstract}

\section{Contents}

Introduction . . . . . . . . . . . . . . . . . . . . . . . . . . . . . . . . . . . . . . . . . . . . . . 1

Defining partial EMT. . . . . . . . . . . . . . . . . . . . . . . . . . . . . . . . . . . . . . . . . . 2

Role of partial EMT in collective migration . . . . . . . . . . . . . . . . . . . . . . . . . . . . . . . . . . . . . . . . . . . . . . . 3

Partial EMT, stemness and drug resistance. . . . . . . . . . . . . . . . . . . . . . . . . . . . . . . . . . . . . . . 4

Stabilizers of partial EMT phenotype . . . . . . . . . . . . . . . . . . . . . . . . . . . . . . . . . . . . . . . . . . . . 5

Hypoxia . . . . . . . . . . . . . . . . . . . . . . . . . . . . . . . . . . . . . . . 5

HIF-1 $\alpha$ mediated regulation of partial EMT and collective migration . . . . . . . . . . . . . . . . . . . . . . . . . . . . . . . . . 6

IBC: a hallmark of pEMT, hypoxia and aggressiveness. . . . . . . . . . . . . . . . . . . . . . . . . . . . . . . . . . . . . . . . . . . . . . . . 7

Conclusion . . . . . . . . . . . . . . . . . . . . . . . . . . . . . . . . . . . . . . . . . 7

Author contributions ....................................................8

Acknowledgement. . . . . . . . . . . . . . . . . . . . . . . . . . . . . . . . . . . . . . . 8

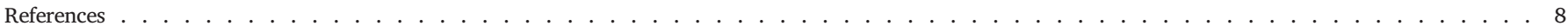

\section{Introduction}

Metastasis, the leading cause of cancer-related deaths worldwide, is a complicated process involving multiple steps such as cancer cell dissemination, invasion, migration, intravasation, extravasation and colonization [1]. Metastasis has extremely high attrition rates (>99.8\%), because of the limited ability of disseminating cells to overcome the challenging and dynamic microenvironments they face during these steps

\footnotetext{
* Corresponding authors.

E-mail addresses: mkjolly@iisc.ac.in, (M.K. Jolly), kuppusamyb@mail.nih.gov. (K. Balamurugan).
} 
of the metastatic cascade [2]. Moreover, the co-occurrence of metastasis with dormancy, drug resistance and tumor relapse further adds to the complexity. Metastasis may involve both active (i.e. cells crawl towards blood vessels) and passive processes (i.e. cells are engulfed by leaky vessels) to different extents; why cells metastasize remains an open question which has recently attracted attention on viewing metastasis from an ecological dynamics perspective [3,4]. However, molecular investigation into mediators of metastasis has revealed various hallmarks of metastasis-initiating cells [2]. The presence of hypoxia (or nutrient stress) to varying degrees in the tumor microenvironment and the ability of cancer cells to migrate collectively as a cluster or cohort have emerged as recent culprits in the process $[5,6]$. Clusters of circulating tumor cells (CTCs) can form a disproportionately higher rate of metastasis as compared to individually migrating CTCs which are typically mesenchymal cells [7-9], suggesting that the disseminating cancer cells follow 'United they stand, divided they fall'.

Signatures of collective migration have been noticed clinically as tumor buds - the clusters of undifferentiated cells mainly in the invasive front of a tumor [10]. As the signatures specific to CTC clusters have begun to being unravelled [11-13], recent efforts have identified some key signaling pathways that can mediate collective migration during metastasis: Wnt/Planar Cell Polarity (PCP) [14], Notch-Jagged signaling $[8,15]$ and HIF-1 $\alpha$ signaling [16]. Cell surface molecules such as podocalyxin and plakoglobin can mediate collective cell migration in breast cancer [7,17]. The phenomenon of tumor budding has been most extensively studied in colorectal cancer [18-21]; recently it has been reported in other carcinomas too - lung cancer [22], breast cancer $[23,24]$, and pancreatic cancer $[25,26]$, where it has been consistently found to be a strong prognostic factor [22,25-27].

These tumor buds in colorectal cancer have been shown to express HIF$1 \alpha[28]$ - one of the major regulators of cellular hypoxic response, at least for acute and intermittent hypoxia [29]. HIF-1 $\alpha$ has also been implicated in driving epithelial-mesenchymal transition (EMT) and its associated traits such as cancer stem cells (CSCs) [30]. EMT is a cell biological process during which epithelial cells lose their traits such as apico-basal polarity and cell-cell adhesion and/or acquire mesenchymal traits such as migration, invasion and adhesion-independent growth [31]. Recent studies have shown that EMT is not a binary process and involves multiple hybrid phenotypes en route EMT [32,33]. Cells in these hybrid E/M phenotype(s) tend to display properties of both epithelial and mesenchymal cells, indicating that EMT is being induced but not completed, also termed as partial EMT [34]. Hybrid E/M phenotype has been implicated in collective cell migration of cancer cells $[35,36]$. The enhanced stemness and/or drug resistance traits of hybrid E/M cells as compared to fully epithelial or fully mesenchymal cells has been reported extensively in breast cancer [37,38], squamous cell carcinoma [39], prostate cancer [40], lung cancer [41,42], ovarian cancer $[43,44]$ and pancreatic cancer [45]. These traits of hybrid E/M cells may offer fitness advantages during various bottlenecks that cancer cells tend to face during the metastatic cascade [46].

Hypoxia is a crucial factor known to be involved in the regulation of various hallmarks of cancer $[47,48]$. While many normal cells die under hypoxia, cancer cells can adapt to hypoxic condition by reprogramming their gene expression profiles that can provide fitness advantages during circulation and establishment of metastasis. Thus, intratumoral hypoxia gene signature identified in vivo has been shown to be better indicators of patient prognosis as compared to those identified by in vitro hypoxic exposure [49]. Hypoxia has been shown to be involved in the induction of EMT, drug resistance and metastasis [50]. Intermittent or cyclic hypoxia - believed to be the most commonly observed scenario in a tumor - has been shown to accelerate tumor growth through cellular adaptation driven by HIF-1 $\alpha$ [51]. Hypoxia can push cells towards a partial EMT [52,53]; however, a better mapping of different extents of hypoxia in terms of duration and/or oxygen concentration with corresponding EMT phenotypes attained remains to be done. In this review, we will briefly discuss mechanisms underlying attaining and stably maintaining the hybrid E/M phenotype(s), its role in mediating stemness and drug resistance, as well as mediators of varying cellular hypoxic response. We will also connect the dots between hypoxia, partial EMT, and collective cell migration and discuss their cross-regulations and synergistic contribution as drivers of metastasis.

\section{Defining partial EMT}

EMT and its reverse mesenchymal-epithelial transition (MET) are evolutionarily conserved cell biological processes involved in embryonic development, tissue repair and wound healing [54,55]. EMT is believed to facilitate dissemination and migration of primary tumor cells to secondary sites where they may undergo MET to form secondary tumors resulting into cancer metastasis [2]. EMT can be associated with various traits crucial to metastasis such as tumor-initiation, therapy resistance, immune evasion and anchorage-independent growths [32,56].

At the molecular level, EMT results in transcriptional inhibition and/or loss of membrane localization of epithelial cell-surface marker E-cadherin and gain of mesenchymal markers such as vimentin, N-cadherin, $\alpha$ smooth muscle actin, and fibronectin [57,58]. Many signaling pathways such as Wnt/ $\beta$-catenin, TGF- $\beta$, FGF, EGFR, Notch, Hedgehog and BMP signaling and/or alterations in the extra-cellular matrix (ECM) stiffness can induce EMT [34]. EMT progression is often associated with increase in the expression of EMT-inducing transcription factors (EMT-TFs) such as ZEB1/2, SNAI1/2, TWIST, FOXC2 and GSC that can receive signals from the abovementioned signaling pathways $[59,60]$. EMT is inhibited and/or reversed by various MET-inducing transcription factors (MET-TFs) such as GRHL2, OVOL1/2, and ELF3/5, many of which form mutually inhibitory feedback loops with one or more EMT-TFs; for instance, GRHL2 and ZEB1 inhibit each other [61-64], so do OVOL1/2 and ZEB1 [65,66]. ELF3 can repress EMT via inhibiting ZEB1 [67], and ELF5 can inhibit SNAI2 [68]. Besides, similar loops are also observed between EMT-inducing TFs and EMT-inhibiting microRNAs such as miR-200 and miR-34 family: miR200/ZEB, miR-34/SNAIL [69-71]. Such feedback loops have been observed at many instances of cellular differentiation and can often allow for the (co)-existence of two (or more) cell states [72] (in this case: epithelial, mesenchymal and hybrid E/M states). Moreover, feedback loops such as ZEB1/ESRP1/CD44 (involving alternative splicing of CD44 by ESRP1, and inhibition of EMT by ESRP1) and ZEB1/HAS2 (involving the secretion of hyaluronic acid (HA) by hyaluronic synthase 2 (HAS2)) have also been shown to regulate EMT and are implicated in stemness, drug resistance and tumor recurrence [73-75].

Recent high-throughput studies have emphasized that EMT is not a binary process but can progress through multiple stable hybrid states $[39,76]$ referred often interchangeably as intermediate EMT, intermediate mesenchymal, partial EMT, hybrid epithelial/mesenchymal, incomplete EMT, semi-mesenchymal, EMT-like, metastable [10]. The importance of hybrid E/M state(s) is supported by observations that induction of fully mesenchymal state results into loss of tumor-initiating and/or colonization potential $[40,77]$ while cells in the hybrid E/M state might display maximum tumor-initiation potential when compared with cells in epithelial or mesenchymal states [38,77-79].

EMT is regulated by complex regulatory networks involving transcription factors, miRNAs, growth factors, non-coding RNAs and epigenetic modifiers [56,57]. Mechanism-based mathematical modelling of these networks has revealed how hybrid E/M states can be attained and stably maintained; for instance, miR-200/ZEB feedback loop can allow three stable states: $\mathrm{miR}^{200} 0^{\text {high }} / \mathrm{ZEB}^{\text {low }}$ (epithelial), miR200 $0^{\text {low }} / \mathrm{ZEB}^{\text {high }}$ (mesenchymal), and miR200 ${ }^{\text {med }} / \mathrm{ZEB}^{\text {med }}$ (hybrid E/M) [80]. Extensions of this model have revealed the existence and signatures of hybrid $\mathrm{E} / \mathrm{M}$ phenotypes, and identified molecules that may be contributing to maintaining these phenotypes such as GRHL2 and OVOL1/2, called as 'phenotypic stability factors' [81-90].

Recent observations using sophisticated techniques such as lineage tracing in patient-derived xenografts, genetically engineered mouse models (GEMM), single-cell RNA-seq, fluorescent activated cell sorting (FACS), immunohistochemistry (IHC), and microfluidic setups have advanced our understanding of hybrid $\mathrm{E} / \mathrm{M}$ cells in vitro and in vivo 
[32,91]. Single-cell studies have provided evidence of hybrid E/M cells co-expressing markers of both epithelial and mesenchymal cells such as $\mathrm{CDH} 1$ (E-cadherin) and VIM (vimentin), thus overcoming the limitations of bulk measurements. For example, experimental studies using FACS analysis have shown breast cancer cells within a population can display phenotypes with varying EMT status, including cells co-expressing both epithelial and mesenchymal markers [78,85]. Similarly, lung cancer cells H1975 have been shown to display hybrid E/M phenotype coexpressing E-cadherin and vimentin over several passages [63]. Multiple single-cell studies have used different epithelial and mesenchymal markers to identify the relative abundance of hybrid E/M cells in cancer cell lines, for example, SNAI/E-cadherin in lung cancer cell lines (A549, LT73, and H460) [92] and in clear cell renal cell carcinoma cells [93], SNAI/E-cadherin/occludin in colorectal cancer [94], epithelial surface marker CD24 and mesenchymal marker CD44 in breast cancer cell line HMLER [78], and vimentin and keratin intermediate filaments in breast cancer cell lines [95]. In addition, hybrid E/M phenotype is also observed in circulating tumor cells (CTCs) [96,97], in vivo mouse models [46], lymph node progression of NSCLC patients [98] and in brain metastases and patient samples $[99,100]$. Moreover, the relative abundance of Ecadherin and vimentin in a cell population is used to classify cell lines into epithelial, mesenchymal and hybrid E/M phenotypes in many cancer types $[44,101,102]$. In a recent study, many hybrid E/M states were observed in skin and mammary primary tumors using combinatorial FACS analysis of EPCAM (epithelial cell adhesion molecule) and CD106, $\mathrm{CD} 61$, and CD51 - the most heterogeneously expressed ones during EMT [39].

Another widely used method to study heterogeneity in EMT status of cells is through single-cell transcriptomic analysis of tumor cells; head and neck squamous cell tumors showed malignant hybrid E/M cells present at the leading edge [103]. Various transcriptomic signature-based metrics have helped quantify the EMT status of cells along a continuous spectrum; these methods exhibit concordant results among themselves [104]. Characterization of hybrid $\mathrm{E} / \mathrm{M}$ cells in tumor samples is gaining importance in terms of deciding the course of treatment and thus unravelling the contributions of cells with different EMT phenotypes in metastasis, drug resistance, and disease aggressiveness - an important aspect enabled only by such high-throughput single-cell analysis [105-107].

Though molecular markers and transcriptomic signatures are extensively used to characterize EMT, cellular motility and morphology traits are another axes to identify phenotypic heterogeneity of cells in a population [108,109]. For example, MDA-MB-468 cells treated with EMTinducing EGF were segregated into cobble, spindle and circular states based on the cellular morphologies. Through quantitative image analysis and mathematical modelling, the authors showed that these morphological state transitions are reversible and depends upon EGF dose and the level of epidermal growth factor receptor (EGFR) phosphorylation [108]. Similarly, Gaussian mixture model focussing on morphometric features associated with transition from compact to elongated phenotype - such as elongation of subcellular nuclear, vimentin and cytoplasmic features - furnished the EMT status of individual cells in a heterogenous cell population [110]. Quantitative epithelialmesenchymal scoring method based on cell morphologies using support vector machine learning was developed to classify cells into epithelial and mesenchymal phenotypes. Using this method, breast cancer cells MDA-MB-231 and MCF-7 showed morphological qualities of both epithelial (rounded) and mesenchymal (elongated) cells suggestive of hybrid E/M phenotype [111], indicating that at least a subpopulation of these seemingly 'pure' epithelial and 'pure' mesenchymal cells [112] may exhibit hybrid E/M phenotype(s) [113]. Whether these morphological changes correspond with molecular signatures of hybrid E/M remains to be identified; thus, EMT may progress at least semiindependently on these molecular and morphological axes [114]. Thus, a falsifiable definition of partial EMT states at biophysical and/ or biochemical states shall be helpful in decoding the unique functional attributes of hybrid E/M phenotypes.

\section{Role of partial EMT in collective migration}

Cancer cells detach from the primary tumor and invade surrounding tissues to successfully metastasize to secondary locations. Broadly speaking, two major modes of invasion methods have been reported: single cell (amoeboid- and mesenchymal- like movement) and collective cell migration [115-117]. Cancer cells can switch between these two invasion strategies depending upon environmental stimuli $[115,118]$. In collective cell migration, cancer cells retain cell-cell adhesions while invading surrounding tissues and can display a variety of migration modalities such as compact cluster/budding of cells, narrow linear strands or broad sheets of cells [119]. A quantitative 3D assessment of tumor budding in pancreatic, breast, colorectal and lung adenocarcinoma tumors has shown that all the invading cells in 3D reconstructed tumor models were part of multicellular cohesive cell clusters, and the single cell migration was exceedingly rare $(<0.0003 \%)$, suggesting collective cell migration as the predominant mechanism of invasion in these cancers [120].

Collectively invading cancer cells comprise of two subpopulations: leader and follower cells. While leader cells are present at invasive front and typically elongated with their actin-driven protrusions extending into their microenvironment, follower cells form the bulk of the multicellular unit at the rear [121]. Leader and follower cells influence the behavior of each other and can also dynamically change their position. In breast cancer, leader cells typically uptake more glucose which gets consumed by forward invasion. When leader cell is depleted of its energy, a follower cell with higher energy takes over the position and role of a leader [122]. In nonsmall cell lung cancer spheroids, follower cells were found to be more proliferative than leader cells and can provide survival advantage to leader cells to ensure invasion [123]. Follower cells have been proposed to pull on the 'future' leader cell at the front, and thus decide which cell becomes the leader [124]. Thus, the leader-follower selection and coordination during collective migration can happen at various non-exclusive levels: mechanical, molecular and interfacial.

Hybrid E/M phenotype(s) have been implicated in collective cell migration. Many traits of hybrid E/M phenotype such as loss of polarity, shift towards spindle shape morphology, partial loss of total and/or membranous E-cadherin and nuclear accumulation of ZEB1 have been shown to be displayed by tumor buds [120]. In Drosophila melanogaster model of colorectal cancer, SNAIL homolog Sna was shown to activate partial EMT which facilitated collective cell migration through basement membrane and muscle fibre, leading to polyclonal metastases [125]. Similarly, collective migration in murine model of squamous cell carcinoma and CTC clusters in head and neck cancer patients can be elicited by SNAIL by inducing claudin-11 [126]. A biophysical model that recapitulates the frequency and size distribution of CTC clusters across cancer types has emphasized the importance of cells in multiple hybrid E/M states in forming CTC clusters of varying sizes [127]. CTC clusters can also contain stromal cells such as platelets, immune cells and cancer-associated fibroblasts [128], which protect CTC cluster from shear stress and immune attack while in blood circulation [129] and may secrete cytokines to facilitate colonization [130].

The association of hybrid $\mathrm{E} / \mathrm{M}$ phenotypes and collective invasion is obfuscated by the variability of molecular mechanisms driving collective invasion. For instance, while primary invasive ductal carcinoma (IDC) and invasive lobular carcinoma (ILC) both display collective invasion, there exist molecular differences: IDC retains E-cadherin and contains adherens junctions and multicellular clusters, ILC lacks E-cadherin and $\beta$-catenin and show CD44 at cell-cell contacts [131]. Similarly, collective cell migration in prostate cancer cells lacking $\alpha$-catenin was shown to be mediated by N-cadherin junctions [132]. Thus, collective migration does not seem to be exclusively mediated via E-cadherin based cell-cell junctions.

Moreover, the EMT status of cells in collectively invading cohort may vary based on spatial localization. In a recent study investigating collective invasion in cancer cell spheroids using 3D assays, CSC-like cells with a hybrid $\mathrm{E} / \mathrm{M}$ phenotype were shown to be at the periphery leading the collective invasion [133]. Similarly, in 3D organoid model of invasive primary breast cancer, the leader cells at the invasive boundary showed collective 
cell migration while staying attached to the follower cells at the rear end. Leader cells displayed altered polarity and frontal protrusion development, yet maintenance of epithelial markers such as cytokeratin 14 (K14) and p63, pointing towards a hybrid E/M phenotype [134]. Collective dissemination of $\mathrm{K} 4^{+}$epithelial cell cluster has been shown to cause distant polyclonal metastases in mouse model of breast cancer [8]. Besides K14, plakoglobin, an essential component of desmosomes and adherens junction, has been shown to be important for CTC cluster formation and consequent metastasis. Its knockdown abrogates CTC cluster and suppresses lung metastasis in vivo. Consistently, in breast cancer patients, the abundance of CTC clusters and plakoglobin shows adverse outcomes, suggesting a clinical validation of observations in mouse models [135]. Similarly, p120-catenin which can stabilize E-cadherin levels by regulating its adhesive binding strength at the cell surface, could also be involved in regulating collective cell migration [136]. Therefore, collective invasion and metastasis can be fuelled by at least a partial retention of epithelial traits [137] such as Ecadherin, which has been shown to be important for survival of invasive ductal carcinomas during invasion, dissemination and colonization [138-140].

Cells in a partial EMT phenotype exhibiting collective migration as clusters were also seen in a mouse model of pancreatic ductal adenocarcinoma (PDAC). However, these cells lacked the membranous expression of Ecadherin due to its accumulation in recycling endosomes and consequent disrupted trafficking, not due to transcriptional inhibition usually seen in EMT. In this mouse model, a subset of tumors exhibited traditional EMT program with transcriptional repression of epithelial program, including the levels of E-cadherin. In contrast to 'partial EMT' cells, these 'complete EMT' cells migrated as single cells [58] (Fig. 1). Thus, the standard analysis of measuring E-cadherin levels at a histopathological or expression level need not be sufficient for evaluating its functional contribution to cell-cell adhesion and collective cell migration [141].

The biochemical and biomechanical interplay of regulation of collective cell migration remains to be better understood. The dynamic and coordinated decision-making in terms of leader and follower cells, as well as their interchange of positions as seen in in vitro setups [122,124,142] may affect the formation and maintenance of CTC clusters and their metastatic propensity. Current observations suggest that leader cells in a collectively migrating sheet are likely to exhibit a hybrid $\mathrm{E} / \mathrm{M}$ phenotype. For instance, in basal-like breast cancer, leader cells showed high motility, co-expressed epithelial (miR-205) and mesenchymal (ZEB2) expression, and retained cell-cell adhesion. This 'partial EMT' program was driven by $\triangle$ NP63 $\alpha$ [143], which was found to be a "phenotypic stability factor" for hybrid E/M phenotype [83] and a downstream target of TGF- $\beta$ signaling [144]. In luminal breast cancer, the leader cells exhibited molecular signatures of partial EMT and collective invasion, and were able to switch back and forth to a follower cell phenotype during collective migration. However, during exchange of leader-follower cell positions, do cells undergo changes in EMT and whether this EMT status change is associated with the changing positions as a cause and/or consequence remains to be identified [145]. Decoding the mechanisms of non-cell-autonomous plasticity in terms of EMT through juxtacrine and/or paracrine mechanisms $[146,147]$ and its effect on CTC clusters, collective invasion and metastatic propensity are some of the open questions that can help resolve contradictory reports about the dispensability of EMT in metastasis.

\section{Partial EMT, stemness and drug resistance}

Successful metastasis of cancer cells from primary tumor to secondary sites requires both the migration of primary cancer cells and their capability to initiate tumor growth at the secondary site. The latter depends upon the tumor initiation potential of the cancer cells, also referred to as 'stemness' [148]. Though still debatable, cancer stem-like cells (CSCs) represent a minor subpopulation of tumor cells capable of tumor initiation (stemness) and clonal expansion through asymmetrical cell division producing both CSCs and non-CSCs [149]. Recent studies have emphasized that cancer cell stemness is a dynamic trait associated with phenotypic plasticity, reflected by switching of CSC to non-CSC and vice versa [150].

Initial reports suggested EMT to be coupled with a gain of stemness [151,152]; however, more recent studies have shown that full EMT might reduce tumor initiation potential of cancer cells $[39,40,77,78]$. Instead, stemness is most likely maintained by cells in hybrid $\mathrm{E} / \mathrm{M}$ state rather than cells in pure $\mathrm{E}$ or pure $\mathrm{M}$ states, as seen across multiple cancer types [46]. A mathematical modelling study coupling regulatory circuits for stemness (LIN28/let-7) and EMT (miR-200/ZEB) has shown that hybrid E/M cells can gain stemness [153]. This positioning of 'stemness window' on the 'EMT axis' is not fixed; it can be fine-tuned by modulatory factors such as OVOL or Notch signaling [66,154]. Experimentally, breast cancer cells expressing signatures of hybrid E/M phenotype were shown to display greater stemness as compared to pure E or M cells [78] (Fig. 1). Similar, hybrid E/M cells isolated from in vivo mouse model of prostate cancer showed comparable or enhanced stemness and invasive characteristics as compared to pure $\mathrm{E}$ and $\mathrm{M}$ cells [40]. Consistent observations were seen in hybrid E/M cells isolated from primary ovarian cancer cultures and ovarian tumors in situ [43]. Thus, further understanding of molecular mediators of coupling between partial EMT and stemness of cancer cells will provide important therapeutic vulnerabilities.

An important clinical barrier in the treatment is the development of drug resistance in cancer cells. Cells undergoing EMT and/or CSCs have

\begin{tabular}{|c|c|}
\hline $\begin{array}{c}\text { Hybrid epithelial/mesenchymal } \\
\text { phenotype in metastasis }\end{array}$ & $\begin{array}{c}\text { 'Complete' mesenchymal } \\
\text { phenotype in metastasis }\end{array}$ \\
\hline $\begin{array}{c}\text { Collective cell migration; can } \\
\text { associate with tumor/stromal cells } \\
\text { to form cellular emboli }\end{array}$ & $\begin{array}{c}\text { Reduced stemness/tumor } \\
\text { initiation capacity }\end{array}$ \\
\hline $\begin{array}{c}\text { Enhanced stemness with high } \\
\text { tumor initiation capacity }\end{array}$ & Less efficient in metastasis \\
\hline $\begin{array}{c}\text { Higher survival in bloodstream } \\
\text { and more efficient in metastasis }\end{array}$ & \\
\hline
\end{tabular}

Fig. 1. Attributes of partial EMT. Comparison of functional attributes of cells displaying hybrid E/M phenotype with those displaying completely mesenchymal cells, during metastasis. 
been shown to be associated with drug resistance as compared to bulk of the tumor and are responsible for tumor regrowth [155]. Accumulating evidence about hybrid $\mathrm{E} / \mathrm{M}$ promoting stemness proposes the hypothesis that hybrid E/M cells may play a strong role in mediating development of drug resistance. For example, taxanes induced a phenotypic transition to a chemotherapy-tolerant state (CD44+/CD24+) which was previously shown to exhibit a hybrid $\mathrm{E} / \mathrm{M}$ phenotype [78] in in vitro and in vivo models of breast cancer subtypes [156]. Similarly, tamoxifen-resistance in MCF-7 breast cancer cells [157], trastuzumab-resistance in HER2-overexpressing breast cancer cells [158] and radiation-resistance in colorectal cancer cells [159] have been shown to be associated with hybrid E/M phenotype. Thus, studying cancer progression by taking a multi-dimensional approach integrating the molecular processes such as EMT, stemness and drugresistance is crucial for a comprehensive systems-level understanding of the dynamics of cancer metastasis and developing effective therapeutics to curb the same [160].

\section{Stabilizers of partial EMT phenotype}

Hybrid E/M state has been earlier suggested to be transient and may not represent a stable phenotype [161]. However, many network-based studies have demonstrated the possibility of relatively high stability of hybrid E/M state [34]. Hybrid E/M phenotype can be stably maintained by different cell lines over multiple passages [63,162]. Moreover, cells isolated from in vivo tumors contain hybrid $\mathrm{E} / \mathrm{M}$ cells $[39,103,163]$. Thus, hybrid E/M state can be a stable phenotype, especially in the presence of phenotypic stability factors (PSFs) such as OVOL, NRF2, GRHL2, NUMB, $\triangle$ NP63 $\alpha$, and NFATc that can promote and stabilize hybrid E/M state and increase the mean residence times of cells in hybrid $\mathrm{E} / \mathrm{M}$ states $[63,83,85,87,162,164-166]$. Knockdown of these PSFs in H1975 lung cancer cell line impaired a stable hybrid E/M phenotype and collective migration and drove the cells towards a complete EMT $[63,165]$. Similarly, knockdown of NRF2 in H1975 and RT4 bladder cancer cells inhibited hybrid E/M phenotype and collective cell migration [162]. Many of these PSFs were found to be involved in transitions among multiple hybrid E/M phenotypes in vivo in squamous cell carcinoma mouse models [32]. Yet, the role of these PSFs in enabling the formation of CTC clusters remains to be shown.

Besides intracellular PSFs, another stabilizer of hybrid E/M state can be combinations of EMT- inducing and MET-inducing signals. For example, MCF-10A and DLD1 cells when treated simultaneously with TGF- $\beta$ and vascular endothelial growth factor A (VEGF-A), demonstrated a hybrid E/M phenotype [166]. Similarly, combinatorial treatment of oral squamous cell carcinoma (OSCC) cells with TGF- $\beta$ and retinoic acid (known inducer of epithelial differentiation and opposes TGF- $\beta$ signaling) resulted into enrichment of post-EMT CSC cell population with CD44 ${ }^{\text {high }}$ EpCAMlow $/{ }^{-} \mathrm{CD} 24^{+}$cell surface markers exhibiting enhanced phenotypic plasticity and therapeutic resistance [167], suggesting enrichment of hybrid E/M state [78]. Other signaling pathways such as SRC proteins, SRC2 and SRC3 [168], colony-stimulating factor 1 (CSF-1) and its receptor CSF-1R [169] have been shown to be involved in maintaining hybrid E/M state.

Another layer of regulation of EMT and hybrid E/M states is epigenetic modifications [170]. Epigenetic changes can control the propensity and frequency of reversible or irreversible EMT or MET [171]. Prolonged exposure of epithelial cells to EMT inducing signal promotes complete EMT and inhibits recovery of these cells back to the epithelial state possibly because of stabilization of long-term transcriptional activity as a result of epigenetic feedback on the miR200/ZEB loop [171-173], thus offering a possible mechanism of different degrees of perturbation required to induce MET [174]. The chromatin modifier protein HMGA2 has been shown to regulate epithelial-mesenchymal plasticity and is upregulated in hybrid E/M and mesenchymal cells of mouse prostate cancer [175]. Different histone modifications and/or CpG methylation are involved in regulation of epithelial genes in the hybrid E/M states [176], including the regulation by GRHL2, a MET-TF which can also facilitate the accessibility of epithelial enhancers
[177]. Besides, the Mbd3/NuRD complex, in combination with activities of HDACs, and Tet2 hydroxylase, are important regulators of epithelialmesenchymal plasticity in EMT models of murine breast cancer [178]. Thus, similar to irreversible EMT, the possibility of irreversible MET (or resistance to EMT) has been recently proposed, owing to epigenetic modulation mediated by GRHL2 [172,179]. Thus, epigenetic feedback operated by various EMT-TFs and/or MET-TFs may alter the dynamics and reversibility of these bidirectional transitions. Future work should focus to decode the integrated regulatory network for achieving and maintaining hybrid E/M phenotypes at transcriptional, post-transcriptional and epigenetic levels will be important in decoding their dynamics and functional attributes.

\section{Hypoxia}

Hypoxia, i.e. reduced oxygen levels, is a crucial factor in tumor microenvironment (TME) that can regulate multiple hallmarks of cancer such as angiogenesis, invasion, EMT, stemness and immune evasion [180,181]. Similar to EMT and/or CSC phenotypes in a tumor, intratumoral hypoxia can also be heterogenous spatially and/or temporally such that certain regions of a tumor are hypoxic $\left(\mathrm{O}_{2}\right.$ concentration between 1 and $2 \%$ or below) while surrounding regions are well oxygenated (normal physiological $\mathrm{O}_{2}$ concentration ranges between 4.6 and 9.4\%) [182,183]. Based on the dynamical profile, tumor hypoxia can be classified into acute, chronic and cyclic hypoxia. Acute hypoxia, also called as perfusion-limited hypoxia, arises due to the temporary blockage of capillaries because of the pressure exerted by the growing tumor mass or irregular erythrocyte flow and lasts for shorter timescales (from few minutes to few hours) as the capillaries may regain blood circulation $[184,185]$. On the other hand, chronic hypoxia, also called as diffusion-limited hypoxia, arises due to the increased distance between the tumor cells and the nearest blood capillaries as a result of increased cellular density due to over-proliferation of cancer cells. It can last for $>24 \mathrm{~h}$ and these regions can show necrosis because of complete oxygen deprivation $[6,184]$. The third category, cyclic hypoxia, also called intermittent hypoxia ( $\mathrm{IH})$, can arise due to a transient shut down of inefficient tumor vasculature resulting into periodic cycles of hypoxia and reoxygenation in tumor cells. The timescale, duration and frequency of intermittent hypoxia-reoxygenation cycles may vary from minutes to days $[29,186-188]$ and may cause reoxygenation injury due to increased oxidative stress and free radical formation leading to tissue damage [189].

Hypoxia inducible factors (HIFs) are known to be the master regulators of gene expression under oxygen-deprived conditions. Transcriptional regulation by HIF proteins is mediated by a heterodimeric HIF complex consisting of HIF $\alpha$ and HIF $\beta$ subunits, which bind to hypoxia responsive element (HRE) present in the promoter region of target genes [190]. While stability of HIFa is oxygen-dependent, HIF $\beta$ is expressed constitutively. Members of prolyl hydroxylase domain (PHD) family function as oxygenlevel sensor, which, under normoxia, hydroxylate two proline residues present at the oxygen-dependent degradation domain of HIFa. These hydroxylated proline residues are recognized by the von-Hippel Lindau (VHL) protein, which acts as substrate recognition protein of an E3 ubiquitin ligase complex that targets HIF $\alpha$ for ubiquitination and proteasomal degradation. Hypoxia inhibits degradation of HIFa by inhibiting PHD resulting in accumulation of HIF $\alpha$ [184]. Three HIF $\alpha$ proteins have been identified in metazoans - HIF- $1 \alpha,-2 \alpha$ and $-3 \alpha$. HIF- $1 \alpha$ and HIF- $2 \alpha$ share $48 \%$ amino acid sequence and have similar structures; however, they are differentially expressed and target different genes [191,192]. While HIF- $1 \alpha$ is ubiquitously expressed, HIF- $2 \alpha$ show tissue specific expression [184]. Similar to HIF-1 $\alpha$ and HIF-2 $\alpha$, HIF- $3 \alpha$ contains bHLH and PAS domains but lacks $\mathrm{C}$-terminal transactivation domain and has been shown to display HIF-1 $\alpha$ regulatory function $[193,194]$.

Hypoxic condition in TME shows variability in terms of duration of hypoxia and levels of oxygen during hypoxia. HIF- $1 \alpha$ and HIF- $2 \alpha$ show differential stability based on hypoxic condition. For example, HIF- $2 \alpha$ but not HIF- $1 \alpha$, has been shown to regulate the hypoxic response at higher oxygen level $\left(5 \% \mathrm{O}_{2}\right)$ in neuroblastoma cells $[195,196]$. Similarly, both HIF-1 $\alpha$ and HIF- $2 \alpha$ are stabilized at $1 \% \mathrm{O}_{2}$ but HIF-1 $\alpha$ stayed active only for small 
duration, while HIF-2 $\alpha$ was stabilized for longer duration, suggesting a crucial role of HIF-1 $\alpha$ in mediating acute responses and switching to HIF- $2 \alpha$ mediated response during prolonged hypoxia. HIF-1 $\alpha$ protein show highest peak at 4-8 $\mathrm{h}$ of hypoxia and then gradually decreases while HIF-2 $\alpha$ stabilizes later and remain stabilized for longer hours (24-72 h) [195,196].

On the other hand, dynamics of HIF- $1 \alpha$ and HIF-2 $\alpha$ stabilization during cyclic hypoxia show completely a different trend. Studies have shown that cyclic hypoxia response is largely, if not entirely, driven by HIF-1 $\alpha$. In different combinations of durations and frequencies of hypoxiareoxygenation (H-R) cycles in cancer and endothelial cells, HIF-1 $\alpha$ protein levels have been observed to be high during the hypoxic phase of H-R cycles but lost during reoxygenation phase [197,198]. Moreover, levels of some of the HIF-1 $\alpha$ regulated genes were found to be upregulated during reoxygenation phase in a stress-granule dependent manner where the sequestered HIF-1 $\alpha$ transcripts were released upon reoxygenation [199]. Multiple regulatory mechanisms have been shown to govern the enhanced stability of HIF-1 $\alpha$ during cyclic hypoxia such as activation of protein kinase A and ROS mediated HIF-1 $\alpha$ stabilization [198,200-202].

With the realization that intermittent/cyclic hypoxia may be a more common phenomenon in TME as compared to chronic hypoxia, recent focus has been moving to identify similarities and differences in response of cells to cyclic hypoxia $v s$. those in chronic hypoxia. For example, under $\mathrm{IH}$, cancer cells have shown to display greater metastasis in mouse models of human cancers, as compared to chronic hypoxia [203-205]. IH has been shown to increase angiogenesis [206-209] and the survival of endothelial cells under proapoptotic stimuli with enhanced migration and tubulogenesis in a HIF-1 $\alpha$-dependent manner [206,207]. Similarly, IH has been shown to increase stem-like properties in breast cancer and neuroblastoma cells [210,211]. In addition, as compared to chronic hypoxia, IH resulted into greater selection of gastric cancer cells with higher selfrenewal and survival properties [212]. Increased HIF-1 $\alpha$ under IH has been shown to upregulate mesenchymal markers such as vimentin, SNAIL, N-cadherin in different cancer cells [213-215]. Moreover, in tumor regions experiencing cyclic hypoxia in glioblastoma xenografts, HIF-1 $\alpha$ has been shown to induce chemoresistance against doxorubicin and $\mathrm{BCNU}$ by upregulating the expression of ABCB1 efflux transporter [216]. Similarly, higher radioresistance in cancer cells under cyclic hypoxia in a HIF-1 $\alpha$-dependent manner has been observed [199,200,207]. Together, these studies suggest that cyclic hypoxia aggravates cancerous properties of tumor cells to a greater extent and the effects could be mediated by HIF- $1 \alpha$ as evidenced by some studies.

\section{HIF-1 $\alpha$ mediated regulation of partial EMT and collective migration}

Cells in a hybrid E/M state show large phenotypic plasticity [113,175], thus potentially enabling cells to switch between different cell states such as CSC and non-CSC, drug-tolerant and drug-sensitive. One common molecular player which might be playing a crucial role in increasing the aggressiveness of cancer cell during IH and partial EMT is HIF-1 $\alpha$. In this section, we will discuss how HIF-1 $\alpha$ is involved in regulating factors associated with EMT and try to connect HIF-1 $\alpha$ with partial EMT. Pancreatic cancer cells grown under hypoxic condition were shown to display partial EMT in HIF-1 $\alpha$ dependent manner with reduced E-cadherin and increased vimentin as compared to cells grown in normoxic or hyperoxic conditions [53].

Hypoxia induced EMT is shown to be mediated by HIF-1 $\alpha$ which has been shown to regulate many molecules involved in EMT [30]. For example, HIF- $1 \alpha$ and TGF $\beta$ has been shown to facilitate the activation of one another in hepatocyte, endothelial and cancer cells [217-220]. In addition, HIF- $1 \alpha$ regulates TGF $\beta 1 /$ SMAD3 signaling to promote breast cancer progression [221]. Similarly, induction of EMT by Wnt/ $\beta$-catenin has been shown to be driven by HIF-1 $\alpha$ in prostate and hepatocellular carcinoma [222,223].

Multiple EMT-TFs are induced by HIF-1 $\alpha$ under hypoxic condition. HIF$1 \alpha$ directly binds to hypoxia response elements (HREs) present in the promoter of TWIST, an inducer of EMT and activates it in hypopharyngeal and breast cancer cells [224]. Regulation of SNAIL by HIF-1 $\alpha$ has been shown through direct binding to HRE in mouse C166 cells [225] and through transcription activation mediated by HDAC3 in cancer cells [226]. Additionally, HIF-1 $\alpha$ mediated activation of SNAIL was found in hepatocellular and lung carcinoma [227,228]. SLUG is also suggested to be regulated by direct binding of HIF- $1 \alpha$ to HREs present in its promoter [229], and ZEB2 activation along with SNAIL activation and E-cadherin repression is shown to be mediated by HIF-1 $\alpha$ in renal cancer cells [230]. HIF$1 \alpha$ mediated direct regulation of ZEB1 is shown in colorectal cancer [231], bladder cancer [232], glioblastoma [233] and pancreatic cancer cells [234].

HIF-1 $\alpha$ mediated activation of cancer-associated fibroblasts (CAFs) in the presence of COX-2 and NF-KB have been shown to induce EMT in prostate cancer cells in a ROS dependent manner [235], suggesting non-cell autonomous EMT induction by proinflammatory signals. Another example of non-cell autonomous signaling leading to induction of EMT is through MMP-2 and MMP-9. ROS stabilized HIF- $1 \alpha$ has shown to induce expression of CAIX in CAFs, which is required for activation of stromal cell delivered MMP-2 and MMP-9 proteins in prostate cancer cells [236]. Proinflammatory cytokines such as TNFa, IL-1 $\beta$ and IL- 6 have been shown to induce HIF-1 $\alpha$ expression, which drives EMT in prostate and renal cancer cells $[237,238]$. In addition, TNF $\alpha$ stabilizes SNAIL by activating NF- $\kappa \beta$ pathway in cancer cell lines $[239,240]$ and NF- $\kappa \beta$ activity induces HIF-1 $\alpha$ transcription and protein accumulation [241].

Under hypoxia, HIF-1 $\alpha$ driven cellular response activates Notch signaling, which has been shown to activate Snail/Slug, Twist and Zeb1/2 as well $[242,243]$. In ovarian cancer cells, Notch signaling can potentiate HIF-1 $\alpha$ expression which stabilized SNAIL in LOX-dependent manner [244]. Thus, multiple feedback loops may regulate the interconnection between hypoxia and EMT. Intermittent hypoxia has shown to increase expression of HIF- $1 \alpha$ and NRF2, a key regulator of oxidative stress [201]. NRF2 and HIF-1 $\alpha$ show a complex crosstalk where NRF2-TRX1 induction enhanced HIF-1 $\alpha$ expression in IH [245]. Moreover, NRF2 has been implicated in stabilization of the hybrid $\mathrm{E} / \mathrm{M}$ state in lung and bladder cancer cells [162], suggesting a regulatory function of HIF-1 $\alpha$ in hybrid E/M phenotype. Exposure of MDA-MB-468 and T47D breast cancer cell line to hypoxia-induced Snail expression without affecting $E$-Cadherin levels consolidates the proposed connection between partial EMT and hypoxia [246]. Finally, the periodic stabilization and degradation of HIF-1 $\alpha$ during hypoxia and reoxygenation of cyclic hypoxia, respectively might result into periodic TGF $\beta$ signaling through BAMBI, a glycoprotein related to type I TGF $\beta$ receptor, which has been shown to be regulated by HIF-1 $\alpha$ under hypoxic condition [247]. This, in turn, may promote hybrid E/M state, because long-term EMT inducing signal has shown to inhibit the recovery of cells back to epithelial state [171].

Hybrid E/M cells are considered to be poised for collective cell migration; however, the current connection between hypoxia and collective cell migration remains unclear in cancer. Tumor buds - clusters of undifferentiated cells seen in invasive edge of colorectal cancer - have been shown to express HIF-1 $\alpha$ [28]. Invasive edge has been reported to contain HIF-1 $\alpha$ positive cells [248], and is enriched in more mesenchymal phenotypes $[15,249,250]$ in other cancers too, but the presence of hypoxia at invasive edge is not exclusive - it has been reported for internal tumor core as well [251]. Therefore, the connection between hypoxic response and a partial or complete EMT remains ambiguous. HIF-1 $\alpha$ has been shown to induce varying degrees of EMT by inhibiting E-cadherin [252-254] and/or upregulating SNAIL and ZEB1 [231,252]. However, HIF-1 $\alpha$ has been shown to favour ameboid migration in epithelial cancers $[16,255]$ by inducing collective-to-ameboid transition (CAT) in breast and head and neck cancer spheroids also, as observed in 3D culture experiments (Fig. 2). Based on TWIST-dependent EMT induction, ameboid cells were classified as EMTlike and EMT-independent cells. HIF-1 $\alpha$ was shown to facilitate ameboid dissemination from collective invasion strands with reduced E-cadherin levels [16]. Enhanced migration of endothelial cells under hypoxia as compared to normoxia in a microfluidic experimental setup has shown to be associated with loosening of intercellular junction resulting from reduced 


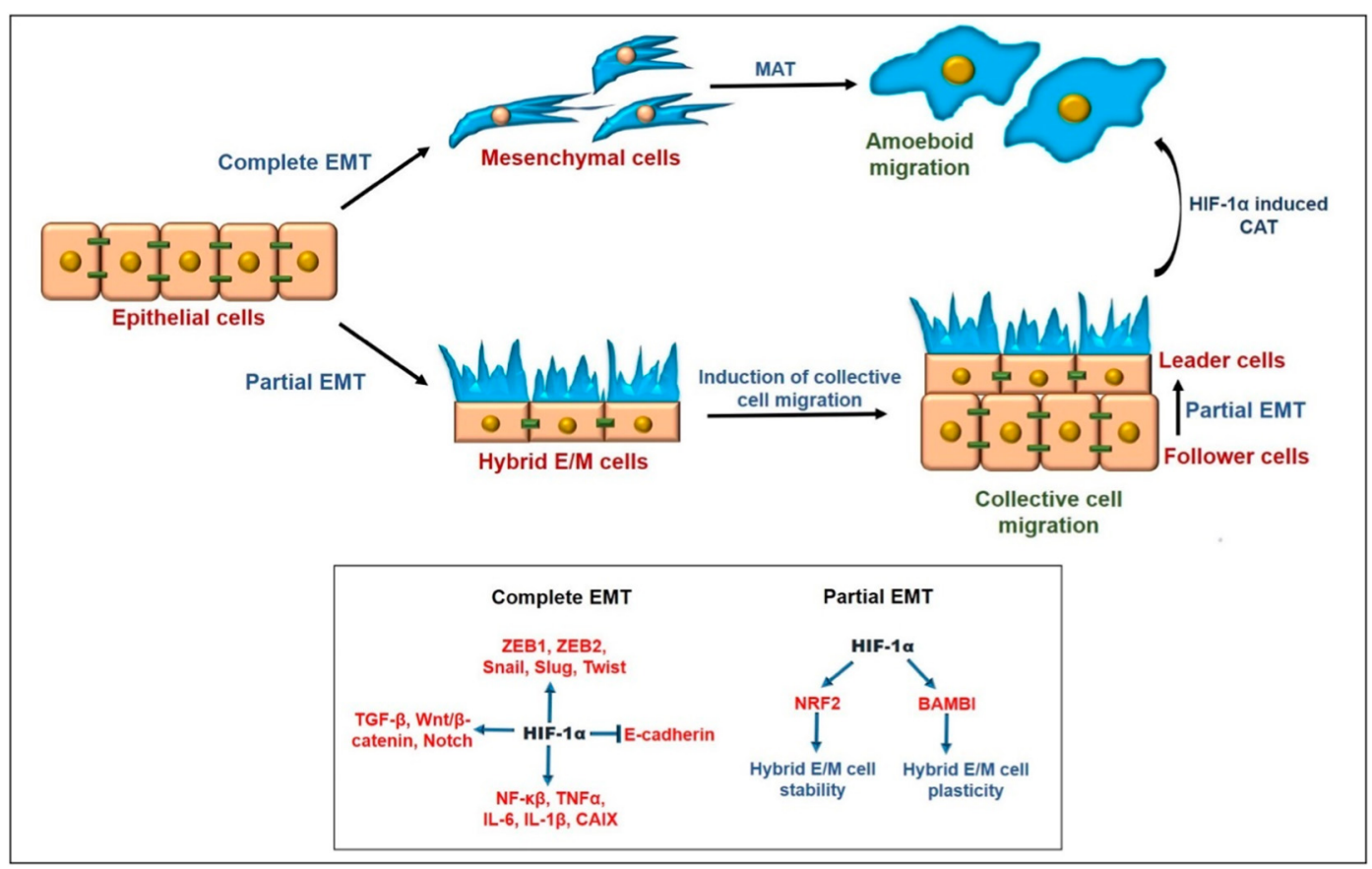

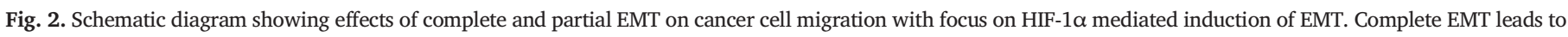

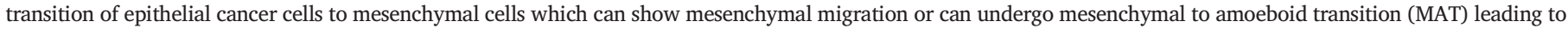

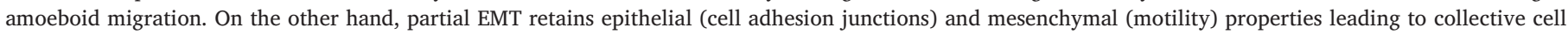

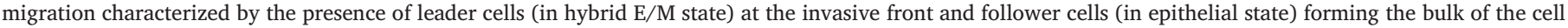

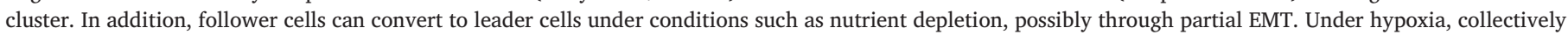

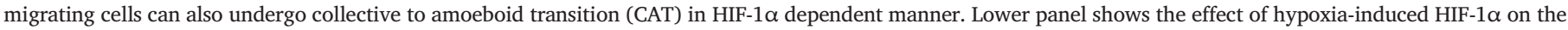
regulators of EMT. Direct HIF-1 $\alpha$ mediated regulation of EMT regulators during partial EMT remains to be better understood.

expression of VE-cadherin [256], consistent with reports of hypoxia involved in directed collective migration of border cells in developmental scenarios [257]. In prostate cancer cells, hypoxia induces the expression of SLUG - often associated with a partial EMT [34] - but does not lead to a complete loss of E-cadherin [258], thus possibly endorsing the hypoxiapartial EMT connection. In brain tumor, cells under hypoxia did not exhibit faster migration as compared to normoxia in either scratch or spheroid based experiment [259]. Thus, further analysis is required to understand how hypoxia/ HIF-1 $\alpha$ can drive partial and/or complete EMT and the corresponding functional consequences for metastasis, bearing in mind the intrinsic plasticity of cancer cell migration modes [260,261].

\section{IBC: a hallmark of pEMT, hypoxia and aggressiveness}

Inflammatory breast cancer (IBC) is a rare type of breast cancer accounting for $2-4 \%$ of all breast cancer patients, but accounts for $7-10 \%$ of breast cancer related mortality [262]. No unique mutational signatures are identified for IBC as compared to non-IBC; instead, epigenetic and/or phenotypic differences are considered to contribute to IBC aggressiveness [263]. IBC is characterized by extensive skin invasion and the formation of tumor cell emboli (clusters) within the breast and dermal lymphatic system; Characteristics of emboli include cell-cell adhesions mediated by $E$-cadherin [264]. Accumulating studies suggest that hypoxia-induced EMT is required for metastasis in many cancer types [221,231-234]: primarily driven by HIF-1 $\alpha$ mediated upregulation of EMT regulators such as TGF- $\beta$ and ZEB1. However, necessity of complete EMT has been debated over recent times and at least revisited in IBC model systems [262,265]. Compelling evidences from both in vitro, and in vivo as well as cell line modelling studies suggest that IBC cells exploit the cell cluster-based metastasis through partial retention of epithelial traits [262]. On the other hand, recent studies highlighted the pro-oncogenic role of $E$-Cadherin wherein E-cadherin promotes metastasis in multiple models of breast cancer [138,266,267]. Several mechanisms have been attributed for the pro-tumorigenic functions of E-Cadherin. For instance, E-cadherin promotes in vivo growth of SUM149 tumor cells through its role in stabilizing HIF-1 $\alpha$ by unknown mechanism(s) leading to regulation of energy metabolism in the aggressive tumor cells [268]. Other mechanisms include, but not limited to, the role of $E$-cadherin in downregulating TGF- $\beta$ signaling [138]. Notably, TGF $\beta$ induced single cell motility involves the regulation of EMT [269]. However, under scenarios of deficient TGF $\beta$ signaling, cells are restricted to collective movement and lymphatic spread after partial EMT [270]. Recent studies showed that SMAD3 nuclear expression, a surrogate marker of TGF $\beta$ signaling, is downregulated in cancer cells from IBC patients as compared to nonIBC [271]. In the absence of SMAD3 expression in IBC tumor emboli, collectively invading cancer cells with higher expression of $E$-Cadherin enables partial EMT that can lead to higher metastatic potential and the tendency for lymphatic dissemination over the hematogenous route [271].

Additionally, under the conditions rich in extracellular matrix, the colony-stimulating factor-1 (CSF-1)/CSF-1R axis plays a key role in driving EMT to E/M phenotype in IBC cells such as SUM149 and SUM190 [169]. Interestingly, CSF-1 is a hypoxia-inducible gene and is directly regulated by HIF-1 [272]; a quantitative proteomics study revealed that exosomes produced by hypoxic tumor cells are highly enriched in immunomodulatory proteins and chemokines including CSF-1 that can modify the metabolic shift in infiltrating monocyte-macrophages. This shift can enable better evasion of the host immunity and enhance tumor progression [273]. Altogether, these studies suggest that hypoxia plays an important role in regulating factors and signaling mechanisms enabling partial EMT culminating in aggressiveness of the tumor growth (Fig. 3).

\section{Conclusion}

Hypoxia has been shown to increase metastasis by augmenting EMT and other hallmarks of cancer. Hybrid E/M phenotype has been implicated in conferring stemness and drug resistance, and shown to facilitate collective cell migration, thus increasing metastasis and tumor initiation 
A

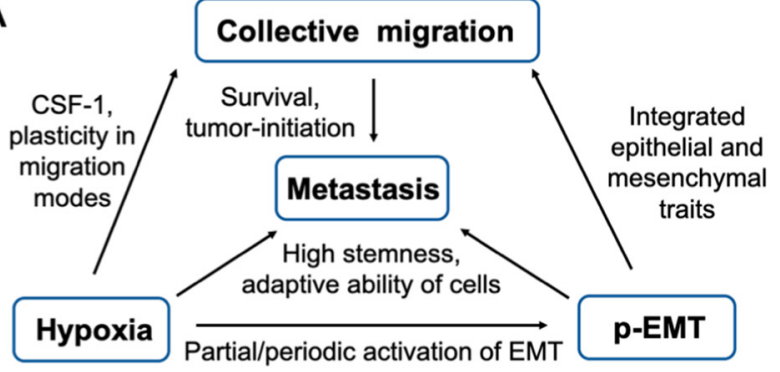

B

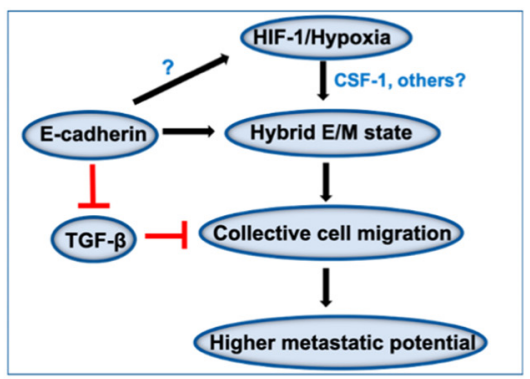

Fig. 3. Interconnections among hypoxia, partial EMT and collective cell migration in metastasis. A) Hypoxia induces hybrid E/M phenotype, which can promote collective migration. Collective migration, hypoxia, and hybrid E/M phenotypes all contribute to metastasis in a potentially synergistic manner. B) Data from breast cancer and IBC model systems show that HIF-1 $\alpha$ induces hybrid E/M phenotype through its target gene CSF-1 which can promote collective migration. While E-Cadherin stabilizes HIF$1 \alpha$ and hypoxic responses through unknown mechanisms, on the other hand, E-Cadherin promotes collective migration through inhibition of TGF- $\beta$, activation of which otherwise leads to single cell migration. A better molecular characterization about the comparative effects of different durations and extents of hypoxia on collective cell migration and metastasis remains to be done.

capability of cancer cells at the secondary sites. Thus, in multi-dimensional regulation of metastasis, a detailed mechanistic and dynamic understanding of how hypoxia, hybrid E/M phenotypes and collective cell migration are interconnected with each other will help to understand molecular details of cancer metastasis and development of novel therapeutics.

\section{Author contributions}

KS, MKJ and KB wrote the manuscript with KS contributing for most of the sections. MKJ and KB supervised the analysis.

\section{Declaration of competing interest}

The authors declare no conflict of interest.

\section{Acknowledgement}

This work was supported by Ramanujan Fellowship awarded to MKJ by Science and Engineering Research Board, Department of Science and Technology, Government of India (SB/S2/RJN-049/2018). KB is supported by the Intramural Research Program of the NIH, National Cancer Institute.

\section{References}

[1] G.P. Gupta, J. Massagué, Cancer metastasis: building a framework, Cell. 127 (2006) 679-695.

[2] T. Celià-Terrassa, Y. Kang, Distinctive properties of metastasis-initiating cells, Genes Dev. 30 (2016) 892-908, https://doi.org/10.1101/gad.277681.116.

[3] M. Bockhorn, R.K. Jain, L.L. Munn, Active versus passive mechanisms in metastasis: do cancer cells crawl into vessels, or are they pushed? Lancet Oncol. 8 (2007) 444-448, https://doi.org/10.1016/S1470-2045(07)70140-7.

[4] S.R. Amend, S. Roy, J.S. Brown, K.J. Pienta, Ecological paradigms to understand the dynamics of metastasis, Cancer Lett. 380 (2016) 237-242, https://doi.org/10.1016/ j.canlet.2015.10.005.

[5] M. Giuliano, A. Shaikh, H.C. Lo, G. Arpino, S. De Placido, X.H. Zhang, M. Cristofanilli, R. Schiff, M.V. Trivedi, Perspective on circulating tumor cell clusters: Why it takes a village to metastasize, Cancer Res. 78 (2018) 845-852, https://doi.org/10.1158/ 0008-5472.CAN-17-2748.

[6] A.R. Nobre, D. Entenberg, Y. Wang, J. Condeelis, J.A. Aguirre-ghiso, The different routes to metastasis via hypoxia-regulated programs, Trends Cell Biol. 28 (2018) 941-956.

[7] N. Aceto, A. Bardia, D.T. Miyamoto, M.C. Donaldson, B.S. Wittner, J.A. Spencer, M. Yu, A. Pely, A. Engstrom, H. Zhu, et al., Circulating tumor cell clusters are oligoclonal precursors of breast cancer metastasis, Cell. 158 (2014) 1110-1122.

[8] K.J. Cheung, V. Padmanaban, V. Silvestri, K. Schipper, J.D. Cohen, A.N. Fairchild, M.A. Gorin, J.E. Verdone, K.J. Pienta, J.S. Bader, A.J. Ewald, Polyclonal breast cancer metastases arise from collective dissemination of keratin 14-expressing tumor cell clusters, Proc. Natl. Acad. Sci. 113 (2016) E854-E863, https://doi.org/10.1073/pnas. 1508541113.

[9] A. Fabisiewicz, E. Grybowska, CTC clusters in cancer progression and metastasis, Med. Oncol. 34 (2017) 12, https://doi.org/10.1007/s12032-016-0875-0.

[10] A. Grigore, M. Jolly, D. Jia, M. Farach-Carson, H. Levine, A.D. Grigore, M.K. Jolly, D. Jia, M.C. Farach-Carson, H. Levine, Tumor budding: the name is EMT, Partial EMT. J. Clin. Med. 5 (2016) 51, https://doi.org/10.3390/jcm5050051.
[11] H. Thangavel, C. De Angelis, S. Vasaikar, R. Bhat, M.K. Jolly, C. Nagi, C.J. Creighton, F. Chen, L.E. Dobrolecki, J.T. George, T. Kumar, N.M. Abdulkareem, S. Mao, A. Nardone, M. Rimawi, C.K. Osborne, M.T. Lewis, H. Levine, B. Zhang, R. Schiff, M. Giuliano, M.V. Trivedi, A CTC-cluster-specific signature derived from OMICS analysis of patientderived xenograft tumors predicts outcomes in basal-like breast cancer, J. Clin. Med. 8 (2019) 1772, https://doi.org/10.3390/jcm8111772.

[12] S. Tripathi, M.K. Jolly, W.A. Woodward, H. Levine, M.W. Deem, Analysis of hierarchical organization in gene expression networks reveals underlying principles of collective tumor cell dissemination and metastatic aggressiveness of inflammatory breast cancer, Front. Oncol. 8 (2018)https://doi.org/10.3389/fonc.2018.00244.

[13] S. Gkountela, F. Castro-Giner, B.M. Szczerba, M. Vetter, J. Landin, R. Scherrer, I. Krol, M.C. Scheidmann, C. Beisel, C.U. Stirnimann, C. Kurzeder, V. Heinzelmann-Schwarz, C. Rochlitz, W.P. Weber, N. Aceto, Circulating tumor cell clustering shapes dna methylation to enable metastasis seeding, Cell. 176 (2019) 98-112.e14, https://doi.org/10. 1016/j.cell.2018.11.046.

[14] K. VanderVorst, C.A. Dreyer, S.E. Konopelski, H. Lee, H.-Y.H. Ho, K.L. Carraway, Wnt/ PCP signaling contribution to carcinoma collective cell migration and metastasis, Cancer Res. 79 (2019) 1719-1729, https://doi.org/10.1158/0008-5472.CAN-18-2757.

[15] F. Bocci, L. Gearhart-Serna, M. Boareto, M. Ribeiro, E. Ben-Jacob, G.R. Devi, H. Levine, J.N. Onuchic, M.K. Jolly, Toward understanding cancer stem cell heterogeneity in the tumor microenvironment, Proc. Natl. Acad. Sci. U. S. A. 116 (2019) 148-157, https:// doi.org/10.1073/pnas.1815345116.

[16] S. Lehmann, V. te Boekhorst, J. Odenthal, R. Bianchi, S. van Helvert, K. Ikenberg, O. Ilina, S. Stoma, J. Xandry, L. Jiang, R. Grenman, M. Rudin, P. Friedl, Hypoxia induces a HIF-1-dependent transition from collective-to-amoeboid dissemination in epithelial cancer cells, Curr. Biol. (2017)https://doi.org/10.1016/j.cub.2016.11.057.

[17] M.L. Graves, J.A. Cipollone, P. Austin, E.M. Bell, J.S. Nielsen, C.B. Gilks, K.M. McNagny, C.D. Roskelley, The cell surface mucin podocalyxin regulates collective breast tumor budding, Breast Cancer Res. 18 (2016) 11, https://doi.org/10.1186/ s13058-015-0670-4.

[18] L. De Smedt, S. Palmans, D. Andel, O. Govaere, B. Boeckx, D. Smeets, E. Galle, J. Wouters, D. Barras, M. Suffiotti, J. Dekervel, T. Tousseyn, G. De Hertogh, H. Prenen, S. Tejpar, D. Lambrechts, X. Sagaert, Expression profiling of budding cells in colorectal cancer reveals an EMT-like phenotype and molecular subtype switching, Br. J. Cancer 116 (2017) 58-65, https://doi.org/10.1038/bjc.2016.382.

[19] K. Satoh, S. Nimura, M. Aoki, M. Hamasaki, K. Koga, H. Iwasaki, Y. Yamashita, H. Kataoka, K. Nabeshima, Tumor Budding in Colorectal Carcinoma Assessed by Cytokeratin Immunostaining and Budding Areas: Possible Involvement of c-Met, Cancer Sci, 2014https://doi.org/10.1111/cas.12530.

[20] M. Karlberg, K. Stenstedt, M. Hallstrom, P. Ragnhammar, C. Lenander, D. Edler, Tumor budding versus mismatch repair status in colorectal cancer -an exploratory analysis, Anticancer Res. (2018)https://doi.org/10.21873/anticanres.12778.

[21] A. Blank, C. Schenker, H. Dawson, G. Beldi, I. Zlobec, A. Lugli, Evaluation of tumor budding in primary colorectal cancer and corresponding liver metastases based on H\&E and pancytokeratin staining, Front. Med. 6 (2019)https://doi.org/10.3389/ fmed.2019.00247.

[22] R. Masuda, H. Kijima, N. Imamura, N. Aruga, Y. Nakamura, D. Masuda, H. Takeichi, N. Kato, T. Nakagawa, M. Tanaka, S. Inokuchi, M. Iwazaki, Tumor budding is a significant indicator of a poor prognosis in lung squamous cell carcinoma patients, Mol. Med. Rep. 6 (2012) 937-943, https://doi.org/10.3892/mmr.2012.1048.

[23] C. Laedrach, B. Salhia, N. Cihoric, I. Zlobec, C. Tapia, Immunophenotypic profile of tumor buds in breast cancer, Pathol. Res. Pract. 214 (2018) 25-29, https://doi.org/ 10.1016/j.prp.2017.11.023.

[24] B.N. Kumarguru, A.S. Ramaswamy, S. Shaik, A. Karri, V.S. Srinivas, B.M. Prashant, Tumor budding in invasive breast cancer - an indispensable budding touchstone, Indian J. Pathol. Microbiol. (2020)https://doi.org/10.4103/IJPM.IJPM_731_18.

[25] P. Lohneis, M. Sinn, F. Klein, S. Bischoff, J.K. Striefler, L. Wislocka, B.V. Sinn, U. Pelzer, H. Oettle, H. Riess, C. Denkert, H. Bläker, A. Jühling, Tumour buds determine prognosis in resected pancreatic ductal adenocarcinoma, Br. J. Cancer (2018)https://doi.org/ 10.1038/s41416-018-0093-y.

[26] E. Karamitopoulou, M. Wartenberg, I. Zlobec, S. Cibin, M. Worni, B. Gloor, A. Lugli, Tumour budding in pancreatic cancer revisited: validation of the ITBCC scoring system, Histopathology. 73 (2018) 137-146, https://doi.org/10.1111/his.13508. 
[27] E. Petrova, V. Zielinski, L. Bolm, C. Schreiber, J. Knief, C. Thorns, P. Bronsert, S. Timme-Bronsert, D. Bausch, S. Perner, T. Keck, U. Wellner, Tumor budding as a prognostic factor in pancreatic ductal adenocarcinoma, Virchows Arch. 476 (2020) 561-568, https://doi.org/10.1007/s00428-019-02719-1.

[28] A. Righi, I. Sarotto, L. Casorzo, S. Cavalchini, E. Frangipane, M. Risio, Tumour budding is associated with hypoxia at the advancing front of colorectal cancer, Histopathology. 66 (2015) 982-990, https://doi.org/10.1111/his.12602.

[29] K. Saxena, M.K. Jolly, Acute vs. Chronic vs. cyclic hypoxia: their differential dynamics, molecular mechanisms, and effects on tumor progression, Biomolecules. (2019) https://doi.org/10.3390/biom9080339.

[30] K. Balamurugan, HIF-1 at the crossroads of hypoxia, inflammation, and cancer, Int. J. Cancer 138 (2016) 1058-1066, https://doi.org/10.1002/ijc.29519.

[31] M.A. Nieto, R.Y. Huang, R.A. Jackson, J.P. Thiery, EMT: 2016, Cell. 166 (2016) 21-45, https://doi.org/10.1016/j.cell.2016.06.028.

[32] I. Pastushenko, C. Blanpain, EMT transition states during tumor progression and metastasis, Trends Cell Biol. 29 (2019) 212-226, https://doi.org/10.1016/j.tcb.2018. 12.001 .

[33] M. Jolly, C. Ward, M.S. Eapen, S. Myers, O. Hallgren, H. Levine, S.S. Sohal, Epithelialmesenchymal transition, a spectrum of states: role in lung development, homeostasis, and disease, Dev. Dyn. 247 (2018) 346-358, https://doi.org/10.1002/dvdy.24541.

[34] M.K. Jolly, M. Boareto, B. Huang, D. Jia, M. Lu, E. Ben-Jacob, J.N. Onuchic, H. Levine, Implications of the hybrid epithelial/mesenchymal phenotype in metastasis, Front. Oncol. 5 (2015) 155, https://doi.org/10.3389/fonc.2015.00155.

[35] M.K. Jolly, S.A. Mani, H. Levine, Hybrid epithelial/mesenchymal phenotype(s): the 'fittest' for metastasis? Biochim. Biophys. Acta - Rev. Cancer. 1870 (2018) 151-157, https://doi.org/10.1016/j.bbcan.2018.07.001.

[36] T.-T. Liao, M.-H. Yang, Hybrid epithelial/mesenchymal state in cancer metastasis: clinical significance and regulatory mechanisms, Cells. 9 (2020) 623.

[37] C. Kröger, A. Afeyan, J. Mraz, E.N. Eaton, F. Reinhardt, Y.L. Khodor, P. Thiru, B. Bierie, X. Ye, C.B. Burge, R.A. Weinberg, Acquisition of a hybrid E/M state is essential for tumorigenicity of basal breast cancer cells, Proc. Natl. Acad. Sci. 116 (2019) 7353-7362, https://doi.org/10.1073/pnas.1812876116.

[38] B. Bierie, S.E. Pierce, C. Kroeger, D.G. Stover, D.R. Pattabiraman, P. Thiru, J. Liu Donaher, F. Reinhardt, C.L. Chaffer, Z. Keckesova, R.A. Weinberg, Integrin- 34 identifies cancer stem cell-enriched populations of partially mesenchymal carcinoma cells, Proc. Natl. Acad. Sci. 114 (2017) E2337-E2346, https://doi.org/10.1073/ pnas.1618298114.

[39] I. Pastushenko, A. Brisebarre, A. Sifrim, M. Fioramonti, T. Revenco, S. Boumahdi, A. Van Keymeulen, D. Brown, V. Moers, S. Lemaire, S. De Clercq, E. Minguijón, C. Balsat, Y. Sokolow, C. Dubois, F. De Cock, S. Scozzaro, F. Sopena, A. Lanas, N. D'Haene, I. Salmon, J.-C. Marine, T. Voet, P.A. Sotiropoulou, C. Blanpain, Identification of the tumour transition states occurring during EMT, Nature. 556 (2018) 463-468, https://doi.org/10.1038/s41586-018-0040-3.

[40] M. Ruscetti, B. Quach, E.L. Dadashian, D.J. Mulholland, W. Hong, Tracking and functional characterization of epithelial-mesenchymal transition and mesenchymal tumor cells during prostate cancer metastasis, Cancer Res. 75 (2015) 2749-2759, https:// doi.org/10.1158/0008-5472.CAN-14-3476.

[41] Y. Zheng, C.C. de la Cruz, L.C. Sayles, C. Alleyne-Chin, D. Vaka, T.D. Knaak, M. Bigos, Y. Xu, C.D. Hoang, J.B. Shrager, H.J. Fehling, D. French, W. Forrest, Z. Jiang, R.A.D. Carano, K.H. Barck, E.L. Jackson, E.A. Sweet-Cordero, A rare population of CD24 + ITGB4 + Notchhi cells drives tumor propagation in NSCLC and requires Notch3 for self-renewal, Cancer Cell 24 (2013) 59-74, https://doi.org/10.1016/j.ccr.2013.05. 021.

[42] V. Fustaino, D. Presutti, T. Colombo, B. Cardinali, G. Papoff, R. Brandi, P. Bertolazzi, G. Felici, G. Ruberti, Characterization of epithelial-mesenchymal transition intermediate/ hybrid phenotypes associated to resistance to EGFR inhibitors in non-small cell lung cancer cell lines, Oncotarget. (2017)https://doi.org/10.18632/oncotarget.21132.

[43] R. Strauss, Z.-Y. Li, Y. Liu, I. Beyer, J. Persson, P. Sova, T. Möller, S. Pesonen, A. Hemminki, P. Hamerlik, C. Drescher, N. Urban, J. Bartek, A. Lieber, Analysis of epithelial and mesenchymal markers in ovarian cancer reveals phenotypic heterogeneity and plasticity, PLoS One 6 (2011), e16186. https://doi.org/10.1371/journal.pone. 0016186.

[44] R.Y.-J. Huang, M.K. Wong, T.Z. Tan, K.T. Kuay, A.H.C. Ng, V.Y. Chung, Y.-S. Chu, N. Matsumura, H.-C. Lai, Y.F. Lee, W.-J. Sim, C. Chai, E. Pietschmann, S. Mori, J.J.H. Low, M. Choolani, J.P. Thiery, An EMT spectrum defines an anoikis-resistant and spheroidogenic intermediate mesenchymal state that is sensitive to e-cadherin restoration by a src-kinase inhibitor, saracatinib (AZD0530), Cell Death Dis. 4 (2013), e915. https://doi.org/10.1038/cddis.2013.442.

[45] T. Yin, H. Wei, S. Gou, P. Shi, Z. Yang, G. Zhao, C. Wang, Cancer stem-like cells enriched in Panc-1 spheres possess increased migration ability and resistance to gemcitabine, Int. J. Mol. Sci. 12 (2011) 1595-1604, https://doi.org/10.3390/ ijms12031595.

[46] M.K. Jolly, J.A. Somarelli, M. Sheth, A. Biddle, S.C. Tripathi, A.J. Armstrong, S.M. Hanash, S.A. Bapat, A. Rangarajan, H. Levine, Hybrid epithelial/mesenchymal phenotypes promote metastasis and therapy resistance across carcinomas, Pharmacol. Ther. 194 (2019) 161-184, https://doi.org/10.1016/j.pharmathera.2018.09.007.

[47] K. Ruan, G. Song, G. Ouyang, Role of hypoxia in the hallmarks of human cancer, J. Cell. Biochem. (2009)https://doi.org/10.1002/jcb.22214.

[48] A.L. Harris, Hypoxia - a key regulatory factor in tumour growth, Nat. Rev. Cancer 2 (2002) 38-47, https://doi.org/10.1038/nrc704

[49] I. Godet, Y.J. Shin, J.A. Ju, I.C. Ye, G. Wang, D.M. Gilkes, Fate-mapping post-hypoxic tumor cells reveals a ROS-resistant phenotype that promotes metastasis, Nat. Commun. (2019)https://doi.org/10.1038/s41467-019-12412-1.

[50] E.B. Rankin, A.J. Giaccia, Hypoxic control of metastasis, Science. 352 (2016) 175-180, https://doi.org/10.1126/science.aaf4405.
[51] D.W. Yoon, D. So, S. Min, J. Kim, M. Lee, R. Khalmuratova, C.-H. Cho, J.-W. Park, H.W. Shin, Accelerated tumor growth under intermittent hypoxia is associated with hypoxia-inducible factor-1-dependent adaptive responses to hypoxia, Oncotarget. 8 (2017) 61592-61603, https://doi.org/10.18632/oncotarget.18644.

[52] M. Singh, X.-J. Tian, V.S. Donnenberg, A.M. Watson, J.Y. Zhang, L.P. Stabile, S.C. Watkins, J. Xing, S. Sant, Targeting the temporal dynamics of hypoxia-induced tumor-secreted factors halts tumor migration, Cancer Res. 79 (2019)https://doi.org/ 10.1158/0008-5472.CAN-18-3151.

[53] S. Chen, X. Chen, W. Li, T. Shan, W.R. Lin, J. Ma, X. Cui, W. Yang, G. Cao, Y. Li, L. Wang, Y. Kang, Conversion of epithelial-to-mesenchymal transition to mesenchymalto-epithelial transition is mediated by oxygen concentration in pancreatic cancer cells, Oncol. Lett. 15 (2018) 7144-7152, https://doi.org/10.3892/ol.2018.8219.

[54] M.A. Nieto, Epithelial plasticity: a common theme in embryonic and cancer cells, Science. 342 (2013) 1234850, https://doi.org/10.1126/science.1234850.

[55] R.C. Stone, I. Pastar, N. Ojeh, V. Chen, S. Liu, K.I. Garzon, M. Tomic-Canic, Epithelialmesenchymal transition in tissue repair and fibrosis, Cell Tissue Res. 365 (2016) 495-506, https://doi.org/10.1007/s00441-016-2464-0.

[56] D. Jia, X. Li, F. Bocci, S. Tripathi, Y. Deng, M.K. Jolly, J.N. Onuchic, H. Levine, Quantifying cancer epithelial-mesenchymal plasticity and its association with stemness and immune response, J. Clin. Med. 8 (2019) 725, https://doi.org/10.3390/jcm8050725.

[57] B. De Craene, G. Berx, Regulatory networks defining EMT during cancer initiation and progression, Nat. Rev. Cancer 13 (2013) 97-110, https://doi.org/10.1038/nrc3447.

[58] N.M. Aiello, R. Maddipati, R.J. Norgard, D. Balli, J. Li, S. Yuan, T. Yamazoe, T. Black, A. Sahmoud, E.E. Furth, D. Bar-Sagi, B.Z. Stanger, EMT subtype influences epithelial plasticity and mode of cell migration, Dev. Cell 45 (2018) 681-695.e4, https://doi. org/10.1016/J.DEVCEL.2018.05.027.

[59] J.H. Taube, J.I. Herschkowitz, K. Komurov, A.Y. Zhou, S. Gupta, J. Yang, K. Hartwell, T.T. Onder, P.B. Gupta, K.W. Evans, B.G. Hollier, P.T. Ram, E.S. Lander, J.M. Rosen, R.A. Weinberg, S.A. Mani, Core epithelial-to-mesenchymal transition interactome gene-expression signature is associated with claudin-low and metaplastic breast cancer subtypes, Proc. Natl. Acad. Sci. U. S. A. (2010)https://doi.org/10.1073/pnas. 1004900107.

[60] A.M. Krebs, J. Mitschke, M.L. Losada, O. Schmalhofer, M. Boerries, H. Busch, M. Boettcher, D. Mougiakakos, W. Reichardt, P. Bronsert, V.G. Brunton, C. Pilarsky, T.H. Winkler, S. Brabletz, M.P. Stemmler, The EMT-activator Zeb1 is a key factor for cell plasticity and promotes metastasis in pancreatic cancer, Nat. Cell Biol. 19 (2017) 518-529, https://doi.org/10.1038/ncb3513.

[61] B. Cieply, J. Farris, J. Denvir, H.L. Ford, S.M. Frisch, Epithelial-mesenchymal transition and tumor suppression are controlled by a reciprocal feedback loop between ZEB1 and grainyhead-like-2, Cancer Res. 73 (2013) 6299-6309, https://doi.org/10.1158/00085472.CAN-12-4082.

[62] S.M. Mooney, V. Talebian, M.K. Jolly, D. Jia, M. Gromala, H. Levine, B.J. McConkey, The GRHL2/ZEB feedback loop-a key axis in the regulation of EMT in breast cancer, J. Cell. Biochem. 118 (2017) 2559-2570, https://doi.org/10.1002/jcb.25974.

[63] M.K. Jolly, S.C. Tripathi, D. Jia, S.M. Mooney, M. Celiktas, S.M. Hanash, S.A. Mani, K.J. Pienta, E. Ben-Jacob, H. Levine, Stability of the hybrid epithelial/mesenchymal phentoype, Oncotarget. 7 (2016) 27067-27084.

[64] V.Y. Chung, T.Z. Tan, M. Tan, M.K. Wong, K.T. Kuay, Z. Yang, J. Ye, J. Muller, C.M. Koh, E. Guccione, J.P. Thiery, R.Y.-J. Huang, GRHL2-miR-200-ZEB1 maintains the epithelial status of ovarian cancer through transcriptional regulation and histone modification, Sci. Rep. 6 (2016) 19943, https://doi.org/10.1038/srep19943.

[65] H. Roca, J. Hernandez, S. Weidner, R.C. McEachin, D. Fuller, S. Sud, T. Schumann, J.E. Wilkinson, A. Zaslavsky, H. Li, C.A. Maher, S. Daignault-Newton, P.N. Healy, K.J. Pienta, Transcription factors OVOL1 and OVOL2 induce the mesenchymal to epithelial transition in human cancer, PLoS One 8 (2013), e76773. https://doi.org/10.1371/ journal.pone.0076773.

[66] M.K. Jolly, D. Jia, M. Boareto, S.A. Mani, K.J. Pienta, E. Ben-Jacob, H. Levine, Coupling the modules of EMT and stemness: A tunable 'stemness window' model, Oncotarget. 6 (2015) 25161-25174, https://doi.org/10.18632/oncotarget.4629.

[67] D. Liu, Y. Skomorovska, J. Song, E. Bowler, R. Harris, M. Ravasz, S. Bai, M. Ayati, K. Tamai, M. Koyuturk, X. Yuan, Z. Wang, Y. Wang, R.M. Ewing, ELF3 is an antagonist of oncogenic-signalling-induced expression of EMT-TF ZEB1, Cancer Biol. Ther. (2019)https://doi.org/10.1080/15384047.2018.1507256.

[68] R. Chakrabarti, J. Hwang, M. Andres Blanco, Y. Wei, M. Lukačišin, R.-A. Romano, K. Smalley, S. Liu, Q. Yang, T. Ibrahim, L. Mercatali, D. Amadori, B.G. Haffty, S. Sinha, Y. Kang, Elf5 inhibits the epithelial-mesenchymal transition in mammary gland development and breast cancer metastasis by transcriptionally repressing Snail2, Nat. Cell Biol. 14 (2012) 1212-1222, https://doi.org/10.1038/ncb2607.

[69] C.P. Bracken, P.A. Gregory, N. Kolesnikoff, A.G. Bert, J. Wang, M.F. Shannon, G.J. Goodall, A double-negative feedback loop between ZEB1-SIP1 and the microRNA200 family regulates epithelial-mesenchymal transition, Cancer Res. 68 (2008) 7846-7854, https://doi.org/10.1158/0008-5472.CAN-08-1942.

[70] U. Burk, J. Schubert, U. Wellner, O. Schmalhofer, E. Vincan, S. Spaderna, T. Brabletz, A reciprocal repression between ZEB1 and members of the miR-200 family promotes EMT and invasion in cancer cells, EMBO Rep. 9 (2008) 582-589, https://doi.org/ 10.1038/embor.2008.74.

[71] H. Siemens, R. Jackstadt, S. Hünten, M. Kaller, A. Menssen, U. Götz, H. Hermeking, miR-34 and SNAIL form a double-negative feedback loop to regulate epithelialmesenchymal transitions, Cell Cycle 10 (2011) 4256-4271, https://doi.org/10. 4161/cc.10.24.18552.

[72] J.X. Zhou, S. Huang, Understanding gene circuits at cell-fate branch points for rational cell reprogramming, Trends Genet. 27 (2011) 55-62, https://doi.org/10.1016/j.tig. 2010.11.002.

[73] J.E. Larsen, V. Nathan, J.K. Osborne, R.K. Farrow, D. Deb, J.P. Sullivan, P.D. Dospoy, A. Augustyn, S.K. Hight, M. Sato, L. Girard, C. Behrens, I.I. Wistuba, A.F. Gazdar, N.K. 
Hayward, J.D. Minna, ZEB1 drives epithelial-to-mesenchymal transition in lung cancer, J. Clin. Invest. 126 (2016) 3219-3235, https://doi.org/10.1172/JCI76725.and.

[74] B.-T. Preca, K. Bajdak, K. Mock, V. Sundararajan, J. Pfannstiel, J. Maurer, U. Wellner, U.T. Hopt, T. Brummer, S. Brabletz, T. Brabletz, A self-enforcing CD44s / ZEB1 feedback loop maintains EMT and stemness properties in cancer cells, Int. J. Cancer 137 (2015) 2566-2577, https://doi.org/10.1002/ijc.29642.

[75] B.-T. Preca, K. Bajdak, K. Mock, W. Lehmann, V. Sundararajan, P. Bronsert, A. MatzgeOgi, V. Orian-Rousseau, S. Brabletz, T. Brabletz, J. Maurer, M.P. Stemmler, A novel ZEB1/HAS2 positive feedback loop promotes EMT in breast cancer, Oncotarget. 8 (2017) 11530-11543, https://doi.org/10.18632/oncotarget.14563.

[76] N.V. Jordan, G.L. Johnson, A.N. Abell, Tracking the intermediate stages of epithelialmesenchymal transition in epithelial stem cells and cancer, Cell Cycle 10 (2011) 2865-2873, https://doi.org/10.4161/cc.10.17.17188.

[77] T. Celià-Terrassa, Ó. Meca-Cortés, F. Mateo, A.M. De Paz, N. Rubio, A. Arnal-Estapé, B.J. Ell, R. Bermudo, A. Díaz, M. Guerra-Rebollo, J.J. Lozano, C. Estarás, C. Ulloa, D. ÁlvarezSimón, J. Milà, R. Vilella, R. Paciucci, M. Martínez-Balbás, A.G. de Herreros, R.R. Gomis, Y. Kang, J. Blanco, P.L. Fernández, T.M. Thomson, Epithelial-mesenchymal transition can suppress major attributes of human epithelial tumor-initiating cells, J. Clin. Invest. 122 (2012) 1849-1868, https://doi.org/10.1172/JCI59218.

78] A. Grosse-Wilde, A. Fouquier d' Herouei, E. McIntosh, G. Ertaylan, A. Skupin, R.E Kuestner, A. del Sol, K.-A. Walters, S. Huang, Stemness of the hybrid epithelial/mesenchymal state in breast cancer and its association with poor survival, PLoS One 10 (2015), e0126522. https://doi.org/10.1371/journal.pone.0126522.

[79] H. Topel, E. Bagirsakci, D. Comez, G. Bagci, G. Cakan-Akdogan, N. Atabey, IncRNA HOTAIR overexpression induced downregulation of c-Met signaling promotes hybrid epithelial/mesenchymal phenotype in hepatocellular carcinoma cells, Cell Commun. Signal 18 (2020) 110, https://doi.org/10.1186/s12964-020-00602-0.

[80] M. Lu, M.K. Jolly, H. Levine, J.N. Onuchic, E. Ben-Jacob, MicroRNA-based regulation of epithelial-hybrid-mesenchymal fate determination, Proc. Natl. Acad. Sci. U. S. A. 110 (2013) 18174-18179, https://doi.org/10.1073/pnas.1318192110.

[81] M.K. Jolly, B.-T.B.-T. Preca, S.C. Tripathi, D. Jia, J.T. George, S.M. Hanash, T. Brabletz, M.P. Stemmler, J. Maurer, H. Levine, Interconnected feedback loops among ESRP1, HAS2, and CD44 regulate epithelial-mesenchymal plasticity in cancer, APL Bioeng. 2 (2018), 031908. https://doi.org/10.1063/1.5024874.

[82] S.N. Steinway, J.G.T. Zañudo, P.J. Michel, D.J. Feith, T.P. Loughran, R. Albert, Combinatorial interventions inhibit TGF $\beta$-driven epithelial-to-mesenchymal transition and support hybrid cellular phenotypes, Npj Syst. Biol. Appl. 1 (2015) 15014, https:// doi.org/10.1038/npjsba.2015.14

[83] K. Biswas, M. Jolly, A. Ghosh, Stability and mean residence times for hybrid epithelial/ mesenchymal phenotype, Phys. Biol. 16 (2019), 025003. https://doi.org/10.1088/ 1478-3975/aaf7b7.

[84] F. Font-Clos, S. Zapperi, C.A.M. La Porta, Topography of epithelial-mesenchymal plasticity, Proc. Natl. Acad. Sci. 115 (2018) 5902-5907, https://doi.org/10.1073/pnas. 1722609115.

85] T. Hong, K. Watanabe, C.H. Ta, A. Villarreal-Ponce, Q. Nie, X. Dai, An Ovol2-Zeb1 mutual inhibitory circuit governs bidirectional and multi-step transition between epithelial and mesenchymal states, PLoS Comput. Biol. 11 (2015), e1004569. https://doi. org/10.1371/journal.pcbi.1004569.

[86] J. Zhang, X.-J. Tian, H. Zhang, Y. Teng, R. Li, F. Bai, S. Elankumaran, J. Xing, TGF- $\beta$ induced epithelial-to-mesenchymal transition proceeds through stepwise activation of multiple feedback loops, Sci. Signal. 7 (2014), ra91. https://doi.org/10.1126/ scisignal.2005304

[87] A.R. Subbalakshmi, D. Kundnani, K. Biswas, A. Ghosh, S.M. Hanash, S.C. Tripathi, M.K. Jolly, NFATc acts as a non-canonical phenotypic stability fatcor for a hybrid epithelial/mesenchymal phenotype, BioRxiv. 047803 (2020)https://doi.org/10.1101/ 2020.04.18.047803.

[88] K. Hari, B. Sabuwala, B.V. Subramani, C. La Porta, S. Zapperi, F. Font-Clos, M.K. Jolly, Identifying inhibitors of epithelial-mesenchymal plasticity using a network topology based approach, Npj Syst. Biol. Appl. 6 (2020) 15, https://doi.org/10.1038/s41540020-0132-1.

[89] S.S. Varankar, S.S. Kamble, A.M. Mali, M.M. More, A. Abraham, B. Kumar, K.J. Pansare, N.J. Narayanan, A. Sen, R.D. Dhake, A.N. Joshi, D. Midha, M. Jolly, Y. Dong, J.A. Clementa, S.A. Bapat, Functional balance between TCF21-Slug defines cellular plasticity and sub-classes in high-grade serous ovarian cancer, Carcinogenesis. (2019)https://doi.org/10.1093/carcin/bgz119.

[90] D. Ramirez, V. Kohar, M. Lu, Toward modeling context-specific EMT regulatory networks using temporal single cell RNA-Seq data, Front. Mol. Biosci. 7 (2020) 54, https://doi.org/10.3389/fmolb.2020.00054.

91] S. Bhatia, P. Wang, A. Toh, E.W. Thompson, New insights into the role of phenotypic plasticity and EMT in driving cancer progression, Front. Mol. Biosci. 7 (2020) 71, https://doi.org/10.3389/fmolb.2020.00071.

[92] F. Andriani, G. Bertolini, F. Facchinetti, E. Baldoli, M. Moro, P. Casalini, R. Caserini, M. Milione, G. Leone, G. Pelosi, U. Pastorino, G. Sozzi, L. Roz, Conversion to stem-cell state in response to microenvironmental cues is regulated by balance between epithelial and mesenchymal features in lung cancer cells, Mol. Oncol. 10 (2016) 253-271, https://doi.org/10.1016/j.molonc.2015.10.002.

[93] V.B. Sampson, J.M. David, I. Puig, P.U. Patil, A.G. de Herreros, G.V. Thomas, A.K. Rajasekaran, Wilms' tumor protein induces an epithelial-mesenchymal hybrid differentiation state in clear cell renal cell carcinoma, PLoS One 9 (2014), e102041. https://doi.org/10.1371/journal.pone.0102041.

[94] M.S.Y. Hiew, H.P. Cheng, C.J. Huang, K.Y. Chong, S.K. Cheong, K.B. Choo, T. Kamarul, Incomplete cellular reprogramming of colorectal cancer cells elicits an epithelial/mesenchymal hybrid phenotype, J. Biomed. Sci. 25 (2018) 57, https://doi.org/10.1186/ s12929-018-0461-1.

[95] M.J.C. Hendrix, E.A. Seftor, R.E.B. Seftor, K.T. Trevor, Experimental co-expression of vimentin and keratin intermediate filaments in human breast cancer cells results in phenotypic interconversion and increased invasive behavior, Am. J. Pathol. 150 (1997) 483-495.

[96] A. Iyer, K. Gupta, S. Sharma, K. Hari, Y.F. Lee, N. Ramalingan, Y.S. Yap, J. West, A.A Bhagat, B.V. Subramani, B. Sabuwala, T.Z. Tan, J.P. Thiery, M.K. Jolly, N.N. Ramalingam, D. Sengupta, Y.S. Yap, J. West, A.A. Bhagat, B.V. Subramani, B. Sabuwala, T.Z. Tan, J.P. Thiery, M.K. Jolly, N.N. Ramalingam, D. Sengupta, Integrative analysis and machine learning based characterization of single circulating tumor cells, J. Clin. Med. 9 (2020), E1206. https://doi.org/10.3390/jcm9041206.

[97] M. Yu, A. Bardia, B.S. Wittner, S.L. Stott, M.E. Smas, D.T. Ting, S.J. Isakoff, J.C Ciciliano, M.N. Wells, A.M. Shah, K.F. Concannon, M.C. Donaldson, L.V. Sequist, E. Brachtel, D. Sgroi, J. Baselga, S. Ramaswamy, M. Toner, D.A. Haber, S Maheswaran, Circulating breast tumor cells exhibit dynamic changes in epithelia and mesenchymal composition, Science. 339 (2013) 580-584, https://doi.org/10. 1126 /science.1228522

[98] C. Emprou, P. Le Van Quyen, J. Jégu, N. Prim, N. Weingertner, E. Guérin, E. Pencreach, M. Legrain, A.C. Voegeli, C. Leduc, B. Mennecier, P.E. Falcoz, A. Olland, N. Santelmo, E. Quoix, G. Massard, D. Guenot, M.P. Chenard, M. Beau-Faller, SNAI2 and TWIST1 in lymph node progression in early stages of NSCLC patients, Cancer Med. (2018)https://doi.org/10.1002/cam4.1545.

[99] D.S. Jeevan, J.B. Cooper, A. Braun, R.A.J. Murali, M. Jhanwar-Uniyal, Molecular pathways mediating metastases to the brain via epithelial-to-mesenchymal transition: genes, proteins, and functional analysis, Anticancer Res. 36 (2016) 523-532.

[100] N. Panchy, C. Azeredo-Tseng, M. Luo, N. Randall, T. Hong, Integrative transcriptomic analysis reveals a multiphasic epithelial-mesenchymal spectrum in cancer and nontumorigenic cells, Front. Oncol. 9 (2020) 1479, https://doi.org/10.3389/fonc.2019. 01479.

[101] M.J. Schliekelman, A. Taguchi, J. Zhu, X. Dai, J. Rodriguez, M. Celiktas, Q. Zhang, A Chin, C.-H. Wong, H. Wang, L. McFerrin, S.A. Selamat, C. Yang, E.M. Kroh, K.S. Garg, C. Behrens, A.F. Gazdar, I.A. Laird-Offringa, M. Tewari, I.I. Wistuba, J.P. Thiery, S.M Hanash, Molecular portraits of epithelial, mesenchymal, and hybrid states in lung adenocarcinoma and their relevance to survival, Cancer Res. 75 (2015) 1789-1800, https://doi.org/10.1158/0008-5472.CAN-14-2535.

[102] S.-M.M. Park, A.B. Gaur, E. Lengyel, M.E. Peter, The miR-200 family determines the epithelial phenotype of cancer cells by targeting the E-cadherin repressors ZEB1 and ZEB2, Genes Dev. 22 (2008) 894-907, https://doi.org/10.1101/gad.1640608.

[103] S.V. Puram, I. Tirosh, A.S. Parikh, A.P. Patel, K. Yizhak, S. Gillespie, C. Rodman, C.L. Luo, E.A. Mroz, K.S. Emerick, D.G. Deschler, M.A. Varvares, R. Mylvaganam, O. RozenblattRosen, J.W. Rocco, W.C. Faquin, D.T. Lin, A. Regev, B.E. Bernstein, Single-cell transcriptomic analysis of primary and metastatic tumor ecosystems in head and neck cancer, Cell. 171 (2017) 1611-1624, https://doi.org/10.1016/j.cell.2017.10.044.

[104] P. Chakraborty, J.T. George, S. Tripathi, H. Levine, M.K. Jolly, Comparative study of transcriptomics-based scoring metrics for the epithelial-hybrid-mesenchymal spectrum, Front. Bioeng. Biotechnol. 8 (2020) 220, https://doi.org/10.3389/fbioe.2020. 00220.

[105] L. Godin, C. Balsat, Y. Van Eycke, J. Allard, C. Royer, M. Remmelink, I. Pastushenko, N.D. Haene, C. Blanpain, I. Salmon, S. Rorive, C. Decaestecker, A novel approach for quantifying cancer cells showing hybrid epithelial/mesenchymal states in large series of tissue samples: towards a new prognostic marker, Cancers (Basel) 12 (2020) 906, https://doi.org/10.3390/cancers12040906.

[106] S. Wu, H. Zhang, S. Fouladdel, H. Li, E. Keller, M.S. Wicha, G.S. Omenn, E. Azizi, Y. Guan, Cellular, transcriptomic and isoform heterogeneity of breast cancer cell line revealed by full-length single-cell RNA sequencing, Comput. Struct. Biotechnol. J. (2020)https://doi.org/10.1016/j.csbj.2020.03.005.

[107] T. Tong, Y. Wang, M.D. Brooks, C. Lee, C. Scott, L. Balzano, M.S. Wicha, J.A. Colacino, Hybrid stem cell states: Insights into the relationship between mammary development and breast cancer using single-cell transcriptomics, Front. Cell Dev. Biol. (2020) https://doi.org/10.3389/fcell.2020.00288 in press.

[108] V. Devaraj, B. Bose, Morphological state transition dynamics in EGF-induced epithelia to mesenchymal transition, J. Clin. Med. 8 (2019) 911, https://doi.org/10.3390/ jcm8070911.

[109] M. Mandal, B. Ghosh, A. Anura, P. Mitra, T. Pathak, J. Chatterjee, Modeling continuum of epithelial mesenchymal transition plasticity, Integr. Biol. 8 (2016) 167-176, https://doi.org/10.1039/C5IB00219B.

[110] S.E. Leggett, J.Y. Sim, J.E. Rubins, Z.J. Neronha, E.K. Williams, I.Y. Wong, Morphological single cell profiling of the epithelial-mesenchymal transition, Integr. Biol. (United Kingdom) (2016)https://doi.org/10.1039/c6ib00139d.

[111] V.K. Lam, T. Nguyen, V. Bui, B.M. Chung, L.-C. Chang, G. Nehmetallah, C.B. Raub Quantitative scoring of epithelial and mesenchymal qualities of cancer cells using machine learning and quantitative phase imaging, J. Biomed. Opt. 25 (2020) 1, https:// doi.org/10.1117/1.JBO.25.2.026002

[112] J.T. George, M.K. Jolly, S. Xu, J.A. Somarelli, H. Levine, Survival outcomes in cancer patients predicted by a partial EMT gene expression scoring metric, Cancer Res. 77 (2017) 6415-6428, https://doi.org/10.1158/0008-5472.CAN-16-3521.

[113] S. Tripathi, P. Chakraborty, H. Levine, M.K. Jolly, A mechanism for epithelialmesenchymal heterogeneity in a population of cancer cells, PLoS Comput. Biol. 16 (2020), e1007619. https://doi.org/10.1101/592691.

[114] K.J. Cheung, A.J. Ewald, Illuminating breast cancer invasion: diverse roles for cell-cell interactions, Curr. Opin. Cell Biol. 30 (2014) 99-111, https://doi.org/10.1016/j.ceb. 2014.07.003.

[115] P. Friedl, K. Wolf, Tumour-cell invasion and migration: diversity and escape mechanisms, Nat. Rev. Cancer (2003)https://doi.org/10.1038/nrc1075.

[116] A.G. Clark, D.M. Vignjevic, Modes of cancer cell invasion and the role of the microenvironment, Curr. Opin. Cell Biol. 36 (2015) 13-22, https://doi.org/10.1016/j.ceb. 2015.06.004

[117] M.L. Taddei, E. Giannoni, A. Morandi, L. Ippolito, M. Ramazzotti, M. Callari, P. Gandellini, P. Chiarugi, Mesenchymal to amoeboid transition is associated with 
stem-like features of melanoma cells, Cell Commun. Signal. 12 (2014) 24, https://doi. org/10.1186/1478-811X-12-24.

[118] O. Ilina, L. Campanello, P.G. Gritsenko, M. Vullings, C. Wang, P. Bult, W. Losert, P. Friedl, Intravital microscopy of collective invasion plasticity in breast cancer, DMM Dis. Model. Mech. (2018)https://doi.org/10.1242/dmm.034330.

[119] P. Friedl, J. Locker, E. Sahai, J.E. Segall, Classifying collective cancer cell invasion, Nat. Cell Biol. 14 (2012) 777-783, https://doi.org/10.1038/ncb2548.

[120] P. Bronsert, K. Enderle-Ammour, M. Bader, S. Timme, M. Kuehs, A. Csanadi, G. Kayser, I. Kohler, D. Bausch, J. Hoeppner, U.T. Hopt, T. Keck, E. Stickeler, B. Passlick, O. Schilling, C.P. Reiss, Y. Vashist, T. Brabletz, J. Berger, J. Lotz, J. Olesch, M. Werner, U.F. Wellner, Cancer cell invasion and EMT marker expression: a three-dimensional study of the human cancer-host interface, J. Pathol. 234 (2014) 410-422, https:// doi.org/10.1002/path.4416.

[121] B. Chen, J. Wu, Y. Tang, Y. Tang, X. Liang, What makes leader cells arise: Intrinsic properties and support from neighboring cells, J. Cell. Physiol. (2020), jcp.29828. https://doi.org/10.1002/jcp.29828.

[122] J. Zhang, K.F. Goliwas, W. Wang, P.V. Taufalele, F. Bordeleau, C.A. Reinhart-King, Energetic regulation of coordinated leader-follower dynamics during collective invasion of breast cancer cells, Proc. Natl. Acad. Sci. U. S. A. 116 (2019) 7867-7872, https:// doi.org/10.1073/pnas.1809964116.

[123] J. Konen, E. Summerbell, B. Dwivedi, K. Galior, Y. Hou, L. Rusnak, A. Chen, J. Saltz, W. Zhou, L.H. Boise, P. Vertino, L. Cooper, K. Salaita, J. Kowalski, A.I. Marcus, Imageguided genomics of phenotypically heterogeneous populations reveals vascular signalling during symbiotic collective cancer invasion, Nat. Commun. (2017)https://doi. org/10.1038/ncomms15078.

[124] M. Vishwakarma, J. Di Russo, D. Probst, U.S. Schwarz, T. Das, J.P. Spatz, Mechanical interactions among followers determine the emergence of leaders in migrating epithelial cell collectives, Nat. Commun. (2018)https://doi.org/10.1038/s41467-01805927-6.

[125] K. Campbell, F. Rossi, J. Adams, I. Pitsidianaki, F.M. Barriga, L. Garcia-Gerique, E. Batlle, J. Casanova, A. Casali, Collective cell migration and metastases induced by an epithelial-to-mesenchymal transition in Drosophila intestinal tumors, Nat. Commun. 10 (2019) 2311, https://doi.org/10.1038/s41467-019-10269-y.

[126] C.-F. Li, J.-Y. Chen, Y.-H. Ho, W.-H. Hsu, L.-C. Wu, H.-Y. Lan, D.S.-S. Hsu, S.-K. Tai, Y.C. Chang, M.-H. Yang, Snail-induced claudin-11 prompts collective migration for tumour progression, Nat. Cell Biol. 21 (2019) 251-262, https://doi.org/10.1038/ s41556-018-0268-z.

[127] F. Bocci, M.K. Jolly, J.N. Onuchic, A biophysical model uncovers the size distribution of migrating cell clusters across cancer types, Cancer Res. 79 (2019) 5527-5535, https://doi.org/10.1158/0008-5472.CAN-19-1726.

[128] N. Aceto, M. Toner, S. Maheswaran, D.A. Haber, En route to metastasis: circulating tumor cell clusters and epithelial-to-mesenchymal transition, Trends Cancer. 1 (2015) 44-52, https://doi.org/10.1016/j.trecan.2015.07.006.

[129] Y. Hong, F. Fang, Q. Zhang, Circulating tumor cell clusters: what we know and what we expect (review), Int. J. Oncol. (2016)https://doi.org/10.3892/ijo.2016.3747.

[130] D.G. Duda, A.M.M.J. Duyverman, M. Kohno, M. Snuderl, E.J.A. Steller, D. Fukumura, R.K. Jain, Malignant cells facilitate lung metastasis by bringing their own soil, Proc. Natl. Acad. Sci. U. S. A. (2010)https://doi.org/10.1073/pnas.1016234107.

[131] A.A. Khalil, O. Ilina, P.G. Gritsenko, P. Bult, P.N. Span, P. Friedl, Collective invasion in ductal and lobular breast cancer associates with distant metastasis, Clin. Exp. Metastasis 34 (2017) 421-429, https://doi.org/10.1007/s10585-017-9858-6.

[132] Y. Cui, S. Yamada, N-cadherin dependent collective cell invasion of prostate cancer cells is regulated by the N-terminus of $\alpha$-catenin, PLoS One (2013)https://doi.org/ 10.1371/journal.pone.0055069.

[133] Q. Quan, X. Wang, C. Lu, W. Ma, Y. Wang, G. Xia, C. Wang, G. Yang, Cancer stem-like cells with hybrid epithelial/mesenchymal phenotype leading the collective invasion, Cancer Sci. 111 (2020) 467-476, https://doi.org/10.1111/cas.14285.

[134] K.J. Cheung, E. Gabrielson, Z. Werb, A.J. Ewald, Collective invasion in breast cancer requires a conserved basal epithelial program, Cell. 155 (2013) 1639-1651, https:// doi.org/10.1016/j.cell.2013.11.029.

[135] B.P. San Juan, M.J. Garcia-Leon, L. Rangel, J.G. Goetz, C.L. Chaffer, The Complexities of Metastasis, Cancers (Basel) 11 (10) (2019) 1575, https://doi.org/10.3390/ cancers11101575.

[136] A.M. Mendonsa, C. Bandyopadhyay, B.M.G. Id, p120-catenin phosphorylation status alters E- cadherin mediated cell adhesion and ability of tumor cells to metastasize, PLoS ONE 15 (2020) 0235337, https://doi.org/10.1371/journal.pone.0235337.

[137] E.R. Shamir, E. Pappalardo, D.M. Jorgens, K. Coutinho, W.-T. Tsai, K. Aziz, M. Auer, P.T. Tran, J.S. Bader, A.J. Ewald, Twist1-induced dissemination preserves epithelial identity and requires E-cadherin, J. Cell Biol. 204 (2014) 839-856, https://doi.org/ $10.1083 /$ jcb. 201306088

[138] V. Padmanaban, I. Krol, Y. Suhail, B.M. Szczerba, N. Aceto, J.S. Bader, A.J. Ewald, Ecadherin is required for metastasis in multiple models of breast cancer, Nature. (2019)https://doi.org/10.1038/s41586-019-1526-3.

[139] Y. Elisha, V. Kalchenko, Y. Kuznetsov, B. Geiger, Dual role of E-cadherin in the regulation of invasive collective migration of mammary carcinoma cells, Sci. Rep. (2018) https://doi.org/10.1038/s41598-018-22940-3.

[140] F.J. Rodriguez, L.J. Lewis-Tuffin, P.Z. Anastasiadis, E-cadherin's dark side: possible role in tumor progression, Biochim. Biophys. Acta 1826 (2012) 23-31, https://doi. org/10.1016/j.bbcan.2012.03.002.

[141] Y.I. Petrova, L. Schecterson, B.M. Gumbiner, Roles for E-cadherin cell surface regulation in cancer, Mol. Biol. Cell (2016)https://doi.org/10.1091/mbc.E16-01-0058.

[142] R. Riahi, J. Sun, S. Wang, M. Long, D.D. Zhang, P.K. Wong, Notch1-Dll4 signalling and mechanical force regulate leader cell formation during collective cell migration, Nat. Commun. 6 (2015) 6656, https://doi.org/10.1038/ncomms7556.
[143] T.T. Dang, M.A. Esparza, E.A. Maine, J.M. Westcott, G.W. Pearson, $\Delta$ Np63 $\alpha$ promotes breast cancer cell motility through the selective activation of components of the epithelial-to-mesenchymal transition program, Cancer Res. 75 (2015) 3925-3935, https://doi.org/10.1158/0008-5472.CAN-14-3363.

[144] N.H.B. Bui, M. Napoli, A.J. Davis, H.A. Abbas, K. Rajapakshe, C. Coarfa, E.R. Flores, Spatiotemporal regulation of $\triangle$ Np63 by TGF $\beta$-regulated miRNAs is essential for cancer metastasis, Cancer Res. (2020)https://doi.org/10.1158/0008-5472.can-19-2733 canres.2733.2019.

[145] C. Yang, M. Cao, Y. Liu, Y. He, Y. Du, G. Zhang, F. Gao, Inducible formation of leader cells driven by CD44 switching gives rise to collective invasion and metastases in luminal breast carcinomas, Oncogene. 38 (2019) 7113-7132, https://doi.org/10.1038/ s41388-019-0899-y.

[146] M. Boareto, M.K. Jolly, A. Goldman, M. Pietilä, S.A. Mani, S. Sengupta, E. Ben-Jacob, H. Levine, J.N. Onuchic, Notch-Jagged signalling can give rise to clusters of cells exhibiting a hybrid epithelial/mesenchymal phenotype, J. R. Soc. Interface 13 (2016)https://doi.org/10.1098/rsif.2015.1106.

[147] D. Neelakantan, H. Zhou, M.U.J. Oliphant, X. Zhang, L.M. Simon, D.M. Henke, C.A Shaw, M.F. Wu, S.G. Hilsenbeck, L.D. White, M.T. Lewis, H.L. Ford, EMT cells increase breast cancer metastasis via paracrine GLI activation in neighbouring tumour cells, Nat. Commun. 8 (2017) 15773, https://doi.org/10.1038/ncomms15773.

[148] L. Ombrato, I. Malanchi, The EMT universe: space between cancer cell dissemination and metastasis initiation, Crit. Rev. Oncog. 19 (2014) 349-361, https://doi.org/10. 1615/CritRevOncog.2014011802.

[149] L. Vermeulen, F. de Sousa e Melo, D.J. Richel, J.P. Medema, The developing cancer stem-cell model: clinical challenges and opportunities, Lancet Oncol. (2012)https:// doi.org/10.1016/S1470-2045(11)70257-1.

[150] P.T. Archana, K. Saxena, R. Murali, M.K. Jolly, R. Nair, Cancer stem cell plasticity - a deadly deal, Front. Mol. Biosci. 7 (2020) 79, https://doi.org/10.3389/fmolb.2020. 00079.

[151] S.A. Mani, W. Guo, M.-J. Liao, E.N. Eaton, A. Ayyanan, A.Y. Zhou, M. Brooks, F. Reinhard, C.C. Zhang, M. Shipitsin, L.L. Campbell, K. Polyak, C. Brisken, J. Yang, R.A. Weinberg, The epithelial-mesenchymal transition generates cells with properties of stem cells, Cell. 133 (2008) 704-715, https://doi.org/10.1016/j.cell.2008.03.027.

[152] A.-P. Morel, M. Lièvre, C. Thomas, G. Hinkal, S. Ansieau, A. Puisieux, Generation of breast cancer stem cells through epithelial-mesenchymal transition, PLoS One 3 (2008), e2888. https://doi.org/10.1371/journal.pone.0002888.

[153] M.K. Jolly, B. Huang, M. Lu, S.A. Mani, H. Levine, E. Ben-Jacob, Towards elucidating the connection between epithelial-mesenchymal transitions and stemness, J. R. Soc Interface 11 (2014) 20140962, https://doi.org/10.1098/rsif.2014.0962.

[154] F. Bocci, M.K. Jolly, J.T. George, H. Levine, J.N. Onuchic, A mechanism-based computational model to capture the interconnections among epithelial-mesenchymal transition, cancer stem cells and Notch-Jagged signaling, Oncotarget. 9 (2018) 29906-29920, https://doi.org/10.18632/oncotarget.25692.

[155] C.D. May, N. Sphyris, K.W. Evans, S.J. Werden, W. Guo, S.A. Mani, Epithelialmesenchymal transition and cancer stem cells: A dangerously dynamic duo in breast cancer progression, Breast Cancer Res. 13 (2011) 202, https://doi.org/10.1186/ bcr2789.

[156] A. Goldman, B. Majumder, A. Dhawan, S. Ravi, D. Goldman, M. Kohandel, P.K. Majumder, S. Sengupta, Temporally sequenced anticancer drugs overcome adaptive resistance by targeting a vulnerable chemotherapy-induced phenotypic transition, Nat. Commun. 6 (2015) 6139, https://doi.org/10.1038/ncomms7139.

[157] S. Hiscox, W.G. Jiang, K. Obermeier, K. Taylor, L. Morgan, R. Burmi, D. Barrow, R.I Nicholson, Tamoxifen resistance in MCF7 cells promotes EMT-like behaviour and in volves modulation of $\beta$-catenin phosphorylation, Int. J. Cancer 118 (2006) 290-301, https://doi.org/10.1002/ijc.21355.

[158] Y. Wu, C. Ginther, J. Kim, N. Mosher, S. Chung, D. Slamon, J.V. Vadgama, Expression of Wnt3 activates Wnt/ $\beta$-catenin pathway and promotes EMT-like phenotype in trastuzumab-resistant HER2-overexpressing breast cancer cells, Mol. Cancer Res. (2012)https://doi.org/10.1158/1541-7786.MCR-12-0155-T.

[159] L.G.D.R. Bastos, P.G. de Marcondes, J.C.M. De-Freitas-Junior, F. Leve, A.L. Mencalha, W.F. de Souza, W.M. de Araujo, M.N. Tanaka, E.S.F.W. Abdelhay, J.A. Morgado-Díaz, Progeny from irradiated colorectal cancer cells acquire an EMT- like phenotype and activate Wnt/B-catenin pathway, J. Cell. Biochem. 115 (2014) 2175-2187, https://doi. org/10.1002/jcb.24896

[160] Y. Suhail, M.P. Cain, K. Vanajan, P.A. Kurywchak, A. Levchenko, R. Kalluri, Kshitiz, systems biology of cancer metastasis, Cell Syst. 9 (2019) 109-127.

[161] P. Savagner, Epithelial-mesenchymal transitions: from cell plasticity to concept elasticity, Curr. Top. Dev. Biol. (2015)https://doi.org/10.1016/bs.ctdb.2014.11.021.

[162] F. Bocci, S.C. Tripathi, M.S.A. Vilchez, J.T. George, J. Casabar, P. Wong, S. Hanash, H Levine, J. Onuchic, M. Jolly, NRF2 activates a partial epithelial-mesenchymal transition and is maximally present in a hybrid epithelial/mesenchymal phenotype, Integr. Biol. 11 (2019) 251-263, https://doi.org/10.1101/390237.

[163] M.K. Jolly, R.J. Murphy, S. Bhatia, H.J. Whitfield, M.J. Davis, E.W. Thompson, Measuring and modelling the epithelial mesenchymal hybrid state in cancer: clinical implications, Preprints (2020) 2020080023, https://doi.org/10.20944/preprints202008. 0023.v1.

[164] D. Jia, M.K. Jolly, M. Boareto, P. Parsana, S.M. Mooney, K.J. Pienta, H. Levine, E. BenJacob, OVOL guides the epithelial-hybrid-mesenchymal transition, Oncotarget. 6 (2015) 15436-15448, https://doi.org/10.18632/oncotarget.3623.

[165] F. Bocci, M.K. Jolly, S.C. Tripathi, M. Aguilar, S.M. Hanash, H. Levine, J.N. Onuchic, Numb prevents a complete epithelial-mesenchymal transition by modulating Notch signalling, J. R. Soc. Interface 14 (2017)https://doi.org/10.1098/rsif.2017.0512.

[166] R. Gould, D.M. Bassen, A. Chakrabarti, J.D. Varner, J. Butcher, Population heterogeneity in the epithelial to mesenchymal transition is controlled by NFAT and 
phosphorylated Sp1, PLoS Comput. Biol. 12 (2016), e005251. https://doi.org/10. 1371/journal.pcbi.1005251.

[167] A. Biddle, L. Gammon, X. Liang, D.E. Costea, I.C. Mackenzie, Phenotypic plasticity determines cancer stem cell therapeutic resistance in Oral squamous cell carcinoma, EBioMedicine. 4 (2016) 138-145, https://doi.org/10.1016/j.ebiom.2016.01.007.

[168] O. Bozickovic, L. Skartveit, A.S.T. Engelsen, T. Helland, K. Jonsdottir, M.H. Flågeng, I.S. Fenne, E. Janssen, J.B. Lorens, L. Bjørkhaug, J.V. Sagen, G. Mellgren, A novel SRC-2-dependent regulation of epithelial-mesenchymal transition in breast cancer cells, J. Steroid Biochem. Mol. Biol. 185 (2019) 57-70, https://doi.org/10.1016/j. jsbmb.2018.07.011.

[169] K. Kai, T. Iwamoto, D. Zhang, L. Shen, Y. Takahashi, A. Rao, A. Thompson, S. Sen, N.T. Ueno, CSF-1/CSF-1R axis is associated with epithelial/mesenchymal hybrid phenotype in epithelial-like inflammatory breast cancer, Sci. Rep. 8 (2018) 9427, https:// doi.org/10.1038/s41598-018-27409-x.

[170] C.Y. Wu, Y.P. Tsai, M.Z. Wu, S.C. Teng, K.J. Wu, Epigenetic reprogramming and posttranscriptional regulation during the epithelial-mesenchymal transition, Trends Genet. (2012)https://doi.org/10.1016/j.tig.2012.05.005.

[171] W. Jia, A. Deshmukh, S.A. Mani, M.K. Jolly, H. Levine, A possible role for epigenetic feedback regulation in the dynamics of the Epithelial-Mesenchymal Transition (EMT), Phys. Biol. 16 (2019), 066004. https://doi.org/10.1101/651620.

[172] L. Eichelberger, M. Saini, H.D. Moreno, C. Klein, J.M. Bartsch, M. Falcone, M. Reitberger, E. Espinet, V. Vogel, E. Graf, T. Schwarzmayr, T.-M. Strom, M. Lehmann, M. Königshoff, N. Pfarr, R. Würth, E. Donato, S. Haas, S. Spaich, M. Sütterlin, A. Schneeweiss, W. Weichert, G. Schotta, A. Trumpp, M.R. Sprick, C. Scheel, Maintenance of epithelial traits and resistance to mesenchymal reprogramming promote proliferation in metastatic breast cancer, BioRxiv (2020) 998823, https://doi.org/10. $1101 / 2020.03 .19 .998823$.

[173] P.A. Gregory, C.P. Bracken, E. Smith, A.G. Bert, J.A. Wright, S. Roslan, M. Morris, L. Wyatt, G. Farshid, Y.-Y. Lim, G.J. Lindeman, M.F. Shannon, P.A. Drew, Y. KhewGoodall, G.J. Goodall, An autocrine TGF-beta/ZEB/miR-200 signaling network regulates establishment and maintenance of epithelial-mesenchymal transition, Mol. Biol. Cell 22 (2011) 1686-1698, https://doi.org/10.1091/mbc.E11-02-0103.

[174] J.A. Somarelli, S. Shetler, M.K. Jolly, X. Wang, S.B. Dewitt, A.J. Hish, S. Gilja, W.C. Eward, K.E. Ware, H. Levine, et al., Mesenchymal-epithelial transition in sarcomas is controlled by the combinatorial expression of MicroRNA 200s and GRHL2, Mol. Cell. Biol. 36 (2016) 2503-2513.

[175] M. Ruscetti, E.L. Dadashian, W. Guo, B. Quach, D.J. Mulholland, J.W. Park, L.M. Tran, N. Kobayashi, D. Bianchi-Frias, Y. Xing, P.S. Nelson, H. Wu, HDAC inhibition impedes epithelial-mesenchymal plasticity and suppresses metastatic, castration-resistant prostate cancer, Oncogene. 35 (2016) 3781-3795, https://doi.org/10.1038/onc.2015. 444.

[176] V.Y. Chung, T.Z. Tan, J. Ye, R.-L. Huang, H.-C. Lai, D. Kappei, H. Wollmann, E. Guccione, R.Y.-J. Huang, The role of GRHL2 and epigenetic remodeling in epithelial-mesenchymal plasticity in ovarian cancer cells, Commun. Biol. 2 (2019) 272, https://doi.org/10.1038/s42003-019-0506-3.

[177] J. Jacobs, M. Atkins, K. Davie, H. Imrichova, L. Romanelli, V. Christiaens, G. Hulselmans, D. Potier, J. Wouters, I.I. Taskiran, G. Paciello, C.B. González-Blas, D. Koldere, S. Aibar, G. Halder, S. Aerts, The transcription factor grainy head primes epithelial enhancers for spatiotemporal activation by displacing nucleosomes, Nat. Genet. 50 (2018) 1011-1020, https://doi.org/10.1038/s41588-018-0140-x.

[178] A. Nihan Kilinc, N. Sugiyama, R.K. Reddy Kalathur, H. Antoniadis, H. Birogul, D. Ishay-Ronen, J.T. George, H. Levine, M. Kumar Jolly, G. Christofori, Histone deacetylases, Mbd3/NuRD, and Tet2 hydroxylase are crucial regulators of epithelial-mesenchymal plasticity and tumor metastasis, Oncogene. 39 (2020) 1498-1513, https://doi.org/10.1038/s41388-019-1081-2.

[179] W. Jia, S. Tripathi, P. Chakraborty, A. Chedere, A. Rangarajan, H. Levine, M.K. Jolly, Epigenetic feedback and stochastic partitioning during cell division can drive resistance to EMT, Oncotarget 11 (2020) 2611-2624, https://doi.org/10.18632/ oncotarget.27651.

[180] D. Hanahan, R.A. Weinberg, Hallmarks of cancer: the next generation, Cell. 144 (2011) 646-674, https://doi.org/10.1016/j.cell.2011.02.013.

[181] R.H. Thomlinson, L.H. Gray, The histological structure of some human lung cancers and the possible implications for radiotherapy, Br. J. Cancer 9 (1955) 539-549, https://doi.org/10.1038/bjc.1955.55.

[182] L.H. Gray, The concentration of oxygen dissolved in tissues at, Br. J. Radiol. 26 (1953) 638-648.

[183] B. Muz, P. de la Puente, F. Azab, A.K. Azab, The role of hypoxia in cancer progression, angiogenesis, metastasis, and resistance to therapy, Hypoxia. 11 (2015) 83-92, https://doi.org/10.2147/HP.S93413.

[184] M.Y. Koh, G. Powis, Passing the baton: the HIF switch, Trends Biochem. Sci. 37 (2012) 364-372, https://doi.org/10.1016/j.tibs.2012.06.004.

[185] J.M. Brown, Evidence for acutely hypoxic cells in mouse tumours, and a possible mechanism of reoxygenation, Br. J. Radiol. 52 (1979) 650-656, https://doi.org/10. 1259/0007-1285-52-620-650.

[186] I. Almendros, D. Gozal, Intermittent hypoxia and cancer: undesirable bed partners? Respir. Physiol. Neurobiol. 256 (2018) 79-86, https://doi.org/10.1016/j.resp.2017. 08.008.

[187] S. Matsumoto, H. Yasui, J.B. Mitchell, M.C. Krishna, Imaging cycling tumor hypoxia, Cancer Res. 70 (2010) 10019-10023, https://doi.org/10.1158/0008-5472.CAN-102821.

[188] D.J. Chaplin, P.L. Olive, R.E. Durand, Intermittent blood flow in a murine tumor: radiobiological effects, Cancer Res. 47 (1987) 597-601.

[189] H. Kimura, R.D. Braun, E.T. Ong, R. Hsu, T.W. Secomb, D. Papahadjopoulos, K. Hong, M.W. Dewhirst, Fluctuations in red cell flux in tumor microvessels can lead to transienthypoxia and reoxygenation in tumor parenchyma, Cancer Res. 56 (1996) 5522-5528.
[190] W.G. Kaelin, P.J. Ratcliffe, Oxygen sensing by metazoans: the central role of the HIF hydroxylase pathway, Mol. Cell 30 (2008) 393-402, https://doi.org/10.1016/j. molcel.2008.04.009.

[191] R. Bartoszewski, A. Moszyńska, M. Serocki, A. Cabaj, A. Polten, R. Ochocka, L. Dell'Italia, S. Bartoszewska, J. Króliczewski, M. Dąbrowski, J.F. Collawn, Primary endothelial cell-specific regulation of hypoxia-inducible factor (HIF)-1 and HIF-2 and their target gene expression profiles during hypoxia, FASEB J. 33 (2019) 7929-7941, https://doi.org/10.1096/fj.201802650RR.

[192] I.G. Ivanova, C.V. Park, N.S. Kenneth, Translating the hypoxic response-the role of HIF protein translation in the cellular response to low oxygen, Cells. 8 (2019) 114 , https://doi.org/10.3390/cells8020114.

[193] Y.Z. Gu, S.M. Moran, J.B. Hogenesch, L. Wartman, C.A. Bradfield, Molecular characterization and chromosomal localization of a third $\alpha$ - class hypoxia inducible factor subunit, HIF3a, Gene Expr. 7 (1998) 205-213.

[194] Y. Makino, A. Kanopka, W.J. Wilson, H. Tanaka, L. Poellinger, Inhibitory PAS domain protein (IPAS) is a hypoxia-inducible splicing variant of the hypoxia-inducible factor$3 \alpha$ locus, J. Biol. Chem. 277 (2002) 32405-32408, https://doi.org/10.1074/jbc. C200328200.

[195] L. Holmquist-Mengelbier, E. Fredlund, T. Löfstedt, R. Noguera, S. Navarro, H. Nilsson, A. Pietras, J. Vallon-Christersson, Å. Borg, K. Gradin, L. Poellinger, S. Påhlman, Recruitment of HIF- $1 \alpha$ and HIF- $2 \alpha$ to common target genes is differentially regulated in neuroblastoma: HIF-2 $\alpha$ promotes an aggressive phenotype, Cancer Cell 10 (2006) 413-423, https://doi.org/10.1016/j.ccr.2006.08.026.

[196] L. Holmquist, A. Jo, S. Pa, Phenotypic persistence after reoxygenation of hypoxic neuroblastoma cells, Int. J. Cancer 225 (2005) 218-225, https://doi.org/10.1002/ijc. 21024.

[197] P. Martinive, F. Defresne, E. Quaghebeur, G. Daneau, N. Crokart, V. Grégoire, B. Gallez, C. Dessy, O. Feron, Impact of cyclic hypoxia on HIF-1 $\alpha$ regulation in endothelial cells - new insights for anti-tumor treatments, FEBS J. 276 (2009) 509-518, https://doi.org/10.1111/j.1742-4658.2008.06798.x.

[198] S. Toffoli, O. Feron, M. Raes, C. Michiels, Intermittent hypoxia changes HIF-1 $\alpha$ phosphorylation pattern in endothelial cells: unravelling of a new PKA-dependent regulation of HIF-1 $\alpha$, Biochim. Biophys. Acta, Mol. Cell Res. 1773 (2007) 1558-1571, https://doi.org/10.1016/j.bbamcr.2007.06.002.

[199] B.J. Moeller, Y. Cao, C.Y. Li, M.W. Dewhirst, Radiation activates HIF-1 to regulate vascular radiosensitivity in tumors: role of reoxygenation, free radicals, and stress granules, Cancer Cell 5 (2004) 429-441.

[200] C.-H. Hsieh, C.-H. Lee, J.-A. Liang, C.-Y. Yu, W.-C. Shyu, Cycling hypoxia increases U87 glioma cell radioresistance via ROS induced higher and long-term HIF-1 signal transduction activity, Oncol. Rep. 24 (2010) 1629-1636, https://doi.org/10.3892/or 00001027.

[201] V. Malec, O.R. Gottschald, S. Li, F. Rose, W. Seeger, J. Hänze, HIF-1 $\alpha$ signaling is augmented during intermittent hypoxia by induction of the Nrf2 pathway in NOX1expressing adenocarcinoma A549 cells, Free Radic. Biol. Med. 48 (2010) 1626-1635, https://doi.org/10.1016/j.freeradbiomed.2010.03.008.

[202] W.-L. Chen, C.-C. Wang, Y.-J. Lin, C.-P. Wu, C.-H. Hsieh, Cycling hypoxia induces chemoresistance through the activation of reactive oxygen species-mediated B-cell lymphoma extra-long pathway in glioblastoma multiforme, J. Transl. Med. 13 (2015) 389, https://doi.org/10.1186/s12967-015-0758-8.

[203] R.A. Cairns, T. Kalliomaki, R.P. Hill, Acute (cyclic) hypoxia enhances spontaneous metastasis of KHT murine tumors, Cancer Res. 61 (2001) 8903-8908.

[204] E.K. Rofstad, K. Galappathi, B. Mathiesen, E.B.M. Ruud, Fluctuating and diffusionlimited hypoxia in hypoxia-induced metastasis, Clin. Cancer Res. 13 (2007) 1971-1978, https://doi.org/10.1158/1078-0432.CCR-06-1967.

[205] A. Chen, J. Sceneay, N. Gödde, T. Kinwel, S. Ham, E.W. Thompson, P.O. Humbert, A. Möller, P.O. Humbert, Intermittent hypoxia induces a metastatic phenotype in breas cancer, Oncogene. (2018) 4214-4225, https://doi.org/10.1038/s41388-018-0259-3.

[206] S. Toffoli, A. Roegiers, O. Feron, M. Van Steenbrugge, N. Ninane, M. Raes, C. Michiels, Intermittent hypoxia is an angiogenic inducer for endothelial cells: role of HIF-1, Angiogenesis. 12 (2009) 47-67, https://doi.org/10.1007/s10456-009-9131-y.

[207] P. Martinive, F. Defresne, C. Bouzin, J. Saliez, F. Lair, V. Grégoire, C. Michiels, C. Dessy, O. Feron, Preconditioning of the tumor vasculature and tumor cells by intermittent hypoxia: implications for anticancer therapies, Cancer Res. 66 (2006) 11736-11744, https://doi.org/10.1158/0008-5472.CAN-06-2056.

[208] J.V. Gaustad, T.G. Simonsen, A.M.A. Roa, E.K. Rofstad, Tumors exposed to acute cyclic hypoxia show increased vessel density and delayed blood supply, Microvasc. Res. 85 (2013) 10-15, https://doi.org/10.1016/j.mvr.2012.11.002.

[209] E.K. Rofstad, J. Gaustad, T.A.M. Egeland, B. Mathiesen, K. Galappathi, Tumors exposed to acute cyclic hypoxic stress show enhanced angiogenesis, perfusion and metastatic dissemination, Int. J. Cancer 127 (2010) 1535-1546, https://doi.org/10.1002/ijc. 25176.

[210] E. Louie, S. Nik, J. Chen, M. Schmidt, B. Song, C. Pacson, X.F. Chen, S. Park, J. Ju, E.I. Chen, Identification of a stem-like cell population by exposing metastatic breast cancer cell lines to repetitive cycles of hypoxia and reoxygenation, Breast Cancer Res. 12 (2010) R94, https://doi.org/10.1186/bcr2773.

[211] V.K. Bhaskara, I. Mohanam, J.S. Rao, S. Mohanam, Intermittent Hypoxia Regulates Stem-Like Characteristics and Differentiation of Neuroblastoma Cells, 7, 2012 1-10, https://doi.org/10.1371/journal.pone.0030905.

[212] Z.F. Miao, T.T. Zhao, Z.N. Wang, Y.Y. Xu, X.Y. Mao, J.H. Wu, X.Y. Liu, H. Xu, Y. You, H.M. Xu, Influence of different hypoxia models on metastatic potential of SGC-7901 gastric cancer cells, Tumor Biol. 35 (2014) 6801-6808, https://doi.org/10.1007/ s13277-014-1928-7.

[213] R. Gupta, C. Chetty, P. Bhoopathi, S. Lakka, S. Mohanam, J.S. Rao, D.H. Dinh, Downregulation of $\mathrm{uPA} / \mathrm{uPAR}$ inhibits intermittent hypoxia-induced epithelialmesenchymal transition (EMT) in DAOY and D283 medulloblastoma cells, Int. J. Oncol. 38 (2011) 733-744, https://doi.org/10.3892/ijo.2010.883. 
[214] L. Liu, W. Liu, L. Wang, T. Zhu, J. Zhong, N.I. Xie, Hypoxia - Inducible Factor 1 Mediates Intermittent Hypoxia - Induced Migration of Human Breast Cancer MDA - MB 231 Cells, 2017 7715-7722, https://doi.org/10.3892/ol.2017.7223.

[215] H. Zhu, D. Wang, L. Zhang, X. Xie, Y. Wu, Y. Liu, G. Shao, Z. Su, Upregulation of autophagy by hypoxia-inducible factor-1 $\alpha$ promotes EMT and metastatic ability of CD133 + pancreatic cancer stem-like cells during intermittent hypoxia, Oncol. Rep. 32 (2014) 935-942, https://doi.org/10.3892/or.2014.3298.

[216] C. Chou, C. Wang, C. Wu, Y. Lin, Y. Lee, Tumor Cycling Hypoxia Induces Chemoresistance in Glioblastoma Multiforme by Upregulating the Expression and Function, 14, 2012 1227-1238.

[217] B.L. Copple, Hypoxia stimulates hepatocyte epithelial to mesenchymal transition by hypoxia-inducible factor and transforming growth factor- $\beta$-dependent mechanisms, Liver Int. 30 (2010) 669-682, https://doi.org/10.1111/j.1478-3231.2010.02205.x.

[218] H. Zhang, H.O. Akman, E.L.P. Smith, J. Zhao, J.E. Murphy-Ullrich, O.A. Batuman, Cellular response to hypoxia involves signaling via Smad proteins, Blood. 101 (2003) 2253-2260, https://doi.org/10.1182/blood-2002-02-0629.

[219] S. McMahon, M. Charbonneau, S. Grandmont, D.E. Richard, C.M. Dubois, Transforming growth factor $\beta 1$ induces hypoxia-inducible factor-1 stabilization through selective inhibition of PHD2 expression, J. Biol. Chem. 281 (2006) 24171-24181, https://doi.org/10.1074/jbc.M604507200.

[220] H. Nishi, T. Nakada, M. Hokamura, Y. Osakabe, O. Itokazu, L.E. Huang, K. Isaka, Hypoxia-inducible factor- 1 transactivates transforming growth factor- $\beta 3$ in trophoblast, Endocrinology. 145 (2004) 4113-4118, https://doi.org/10.1210/en.20031639.

[221] J. Peng, X. Wang, L. Ran, J. Song, R. Luo, Y. Wang, Hypoxia-inducible factor $1 \alpha$ regulates the transforming growth factor $\beta 1$ /SMAD family member 3 pathway to promote breast cancer progression, J. Breast Cancer 21 (2018) 259, https://doi.org/10.4048/ jbc.2018.21.e42.

[222] Y.-G. Jiang, Y. Luo, D. He, X. Li, L. Zhang, T. Peng, M.-C. Li, Y.-H. Lin, Role of Wnt/Bcatenin signaling pathway in epithelial-mesenchymal transition of human prostate cancer induced by hypoxia-inducible factor-1 $\alpha$, Int. J. Urol. 14 (2007) 1034-1039, https://doi.org/10.1111/j.1442-2042.2007.01866.x.

[223] Q. Zhang, X. Bai, W. Chen, T. Ma, Q. Hu, C. Liang, S. Xie, C. Chen, L. Hu, S. Xu, T. Liang, Wnt/ß-catenin signaling enhances hypoxia-induced epithelial-mesenchymal transition in hepatocellular carcinoma via crosstalk with hif-1 $\alpha$ signaling, Carcinogenesis. 34 (2013) 962-973, https://doi.org/10.1093/carcin/bgt027.

[224] M.H. Yang, M.Z. Wu, S.H. Chiou, P.M. Chen, S.Y. Chang, C.J. Liu, S.C. Teng, K.J. Wu, Direct regulation of TWIST by HIF-1 $\alpha$ promotes metastasis, Nat. Cell Biol. 10 (2008) 295-305, https://doi.org/10.1038/ncb1691.

[225] D. Luo, J. Wang, J. Li, M. Post, Mouse Snail is a target gene for HIF, Mol. Cancer Res. 9 (2011) 234-245, https://doi.org/10.1158/1541-7786.MCR-10-0214.

[226] M.-Z. Wu, Y.-P. Tsai, M.-H. Yang, C.-H. Huang, S.-Y. Chang, C.-C. Chang, S.-C. Teng, K.$\mathrm{J}$. Wu, Interplay between HDAC3 and WDR5 is essential for hypoxia-induced epithelial-mesenchymal transition, Mol. Cell 43 (2011) 811-822, https://doi.org/10. 1016/j.molcel.2011.07.012.

[227] L. Zhang, G. Huang, X. Li, Y. Zhang, Y. Jiang, J. Shen, J. Liu, Q. Wang, J. Zhu, X. Feng, J. Dong, C. Qian, Hypoxia induces epithelial-mesenchymal transition via activation of SNAI1 by hypoxia-inducible factor - $1 \alpha$ in hepatocellular carcinoma, BMC Cancer 13 (2013) 108, https://doi.org/10.1186/1471-2407-13-108.

[228] K.-H. Liu, Y.-T. Tsai, S.-Y. Chin, W.-R. Lee, Y.-C. Chen, S.-C. Shen, Hypoxia stimulates the epithelial-to-mesenchymal transition in lung cancer cells through accumulation of nuclear $\beta$-catenin, Anticancer Res. 38 (2018) 6299-6308, https://doi.org/10.21873/ anticanres.12986.

[229] G. Storci, P. Sansone, S. Mari, G. D'Uva, S. Tavolari, T. Guarnieri, M. Taffurelli, C. Ceccarelli, D. Santini, P. Chieco, K.B. Marcu, M. Bonafè, TNFalpha up-regulates SLUG via the NF-kappaB/HIF1alpha axis, which imparts breast cancer cells with a stem cell-like phenotype, J. Cell. Physiol. (2010)https://doi.org/10.1002/jcp. 22264.

[230] A.J. Evans, R.C. Russell, O. Roche, T.N. Burry, J.E. Fish, V.W.K. Chow, W.Y. Kim, A. Saravanan, M.A. Maynard, M.L. Gervais, R.I. Sufan, A.M. Roberts, L.A. Wilson, M. Betten, C. Vandewalle, G. Berx, P.A. Marsden, M.S. Irwin, B.T. Teh, M.A.S. Jewett, M. Ohh, VHL promotes E2 box-dependent E-cadherin transcription by HIF-mediated regulation of SIP1 and snail, Mol. Cell. Biol. 27 (2007) 157-169, https://doi.org/10. 1128/MCB.00892-06.

[231] W. Zhang, X. Shi, Y. Peng, M. Wu, P. Zhang, R. Xie, Y. Wu, Q. Yan, S. Liu, J. Wang, HIF$1 \alpha$ promotes epithelial-mesenchymal transition and metastasis through direct regulation of ZEB1 in colorectal cancer, PLoS One 10 (2015), e0129603. https://doi.org/ 10.1371/journal.pone.0129603.

[232] J. Zhu, Z. Huang, M. Zhang, W. Wang, H. Liang, J. Zeng, K. Wu, X. Wang, J. Hsieh, P. Guo, J. Fan, HIF-1 $\alpha$ promotes ZEB1 expression and EMT in a human bladder cancer lung metastasis animal model, Oncol. Lett. 15 (2018) 3482-3489, https://doi.org/ 10.3892/ol.2018.7764.

[233] J.V. Joseph, S. Conroy, K. Pavlov, P. Sontakke, T. Tomar, E. Eggens-Meijer, V. Balasubramaniyan, M. Wagemakers, W.F.A. den Dunnen, F.A.E. Kruyt, Hypoxia enhances migration and invasion in glioblastoma by promoting a mesenchymal shift mediated by the HIF1 $\alpha$-ZEB1 axis, Cancer Lett. (2015)https://doi.org/10.1016/j.canlet. 2015.01.010

[234] S.J. Deng, H.Y. Chen, Z. Ye, S.C. Deng, S. Zhu, Z. Zeng, C. He, M.L. Liu, K. Huang, J.X. Zhong, F.Y. Xu, Q. Li, Y. Liu, C.Y. Wang, G. Zhao, Hypoxia-induced LncRNA-bx111 promotes metastasis and progression of pancreatic cancer through regulating ZEB1 transcription, Oncogene. (2018)https://doi.org/10.1038/s41388-018-0382-1.

[235] E. Giannoni, F. Bianchini, L. Calorini, P. Chiarugi, Cancer associated fibroblasts exploit reactive oxygen species through a proinflammatory signature leading to epithelial mesenchymal transition and stemness, Antioxid. Redox Signal. 14 (2011) 2361-2371, https://doi.org/10.1089/ars.2010.3727.
[236] T. Fiaschi, E. Giannoni, M.L. Taddei, P. Cirri, A. Marini, G. Pintus, C. Nativi, B. Richichi, A. Scozzafava, F. Carta, E. Torre, C.T. Supuran, P. Chiarugi, Carbonic anhydrase IX from cancer-associated fibroblasts drives epithelial-mesenchymal transition in prostate carcinoma cells, Cell Cycle (2013)https://doi.org/10.4161/cc.24902.

[237] H.-J. Kim, J.-W. Park, Y.-S. Cho, C.-H. Cho, J.-S. Kim, H.-W. Shin, D.H. Chung, S.J. Kim, Y.-S. Chun, Pathogenic role of HIF-1 $\alpha$ in prostate hyperplasia in the presence of chronic inflammation, Biochim. Biophys. Acta Mol. basis Dis. 1832 (2013) 183-194, https://doi.org/10.1016/j.bbadis.2012.09.002.

[238] M.J. Chuang, K.H. Sun, S.J. Tang, M.W. Deng, Y.H. Wu, J.S. Sung, T.L. Cha, G.H. Sun, Tumor-derived tumor necrosis factor-alpha promotes progression and epithelialmesenchymal transition in renal cell carcinoma cells, Cancer Sci. (2008)https://doi. org/10.1111/j.1349-7006.2008.00756.x.

[239] Y. Wu, B.P. Zhou, TNF- $\alpha /$ NFK-B/Snail pathway in cancer cell migration and invasion, Br. J. Cancer (2010)https://doi.org/10.1038/sj.bjc.6605530.

[240] Y. Wu, J. Deng, P.G. Rychahou, S. Qiu, B.M. Evers, B.P. Zhou, Stabilization of snail by $\mathrm{NF}-\mathrm{kB}$ is required for inflammation-induced cell migration and invasion, Cancer Cell 15 (2009) 416-428, https://doi.org/10.1016/j.ccr.2009.03.016.

[241] J. Rius, M. Guma, C. Schachtrup, K. Akassoglou, A.S. Zinkernagel, V. Nizet, R.S. Johnson, G.G. Haddad, M. Karin, NF-kB links innate immunity to the hypoxic response through transcriptional regulation of HIF-1 $\alpha$, Nature. (2008)https://doi.org/10.1038/ nature06905.

[242] J.P. Thiery, H. Acloque, R.Y.J. Huang, M.A. Nieto, Epithelial-mesenchymal transitions in development and disease, Cell. 139 (2009) 871-890, https://doi.org/10.1016/j. cell.2009.11.007.

[243] Y. Wang, J. Shi, K. Chai, X. Ying, B. Zhou, The role of Snail in EMT and tumorigenesis, Curr. Cancer Drug Targets 13 (2013) 963-972, https://doi.org/10.2174/ 15680096113136660102.

[244] C. Sahlgren, M.V. Gustafsson, S. Jin, L. Poellinger, U. Lendahl, Notch signaling mediates hypoxia-induced tumor cell migration and invasion, Proc. Natl. Acad. Sci. U. S. A. 105 (2008) 6392-6397, https://doi.org/10.1073/pnas.0802047105.

[245] R. Toth, N. Warfel, Strange bedfellows: nuclear factor, erythroid 2-like 2 (Nrf2) and hypoxia-inducible factor 1 (HIF-1) in tumor hypoxia, Antioxidants. 6 (2017) 27, https://doi.org/10.3390/antiox6020027.

[246] K. Lundgren, B. Nordenskjöld, G. Landberg, Hypoxia, Snail and incomplete epithelialmesenchymal transition in breast cancer, Br. J. Cancer (2009)https://doi.org/10. 1038/sj.bjc.6605369.

[247] I. Raykhel, F. Moafi, S.M. Myllymäki, P.G. Greciano, K.S. Matlin, J.V. Moyano, A. Manninen, J. Myllyharju, BAMBI is a novel HIF1-dependent modulator of TGFßmediated disruption of cell polarity during hypoxia, J. Cell Sci. (2018)https://doi. org/10.1242/jcs.210906.

[248] N. Rohwer, S. Lobitz, K. Daskalow, T. Jöns, M. Vieth, P.M. Schlag, W. Kemmner, B. Wiedenmann, T. Cramer, M. Höcker, HIF-1 $\alpha$ determines the metastatic potential of gastric cancer cells, Br. J. Cancer 100 (2009) 772-781, https://doi.org/10.1038/sj. bjc.6604919.

[249] S. Liu, Y. Cong, D. Wang, Y. Sun, L. Deng, Y. Liu, R. Martin-Trevino, L. Shang, S.P. McDermott, M.D. Landis, S. Hong, A. Adams, R. D'Angelo, C. Ginestier, E. CharafeJauffret, S.G. Clouthier, D. Birnbaum, S.T. Wong, M. Zhan, J.C. Chang, M.S. Wicha, Breast cancer stem cells transition between epithelial and mesenchymal states reflective of their normal counterparts, Stem Cell Rep. 2 (2014) 78-91, https://doi.org/ 10.1016/j.stemcr.2013.11.009.

[250] T. Brabletz, A. Jung, S. Reu, M. Porzner, F. Hlubek, L.A. Kunz-Schughart, R. Knuechel, T. Kirchner, Variable beta-catenin expression in colorectal cancers indicates tumor progression driven by the tumor environment, Proc. Natl. Acad. Sci. U. S. A. 98 (2001) 10356-10361, https://doi.org/10.1073/pnas.171610498.

[251] A. Ron, X.L. Deán-Ben, S. Gottschalk, D. Razansky, Volumetric optoacoustic imaging unveils high-resolution patterns of acute and cyclic hypoxia in a murine model of breast cancer, Cancer Res. 79 (18) (2019) 4767-4775 canres.3769.2018. https:// doi.org/10.1158/0008-5472.can-18-3769.

[252] T. Imai, A. Horiuchi, C. Wang, K. Oka, S. Ohira, T. Nikaido, I. Konishi, Hypoxia attenuates the expression of E-cadherin via up-regulation of SNAIL in ovarian carcinoma cells, Am. J. Pathol. 163 (2003) 1437-1447, https://doi.org/10.1016/S0002-9440 (10)63501-8

[253] M.A. Esteban, M.G.B. Tran, S.K. Harten, P. Hill, M.C. Castellanos, A. Chandra, R. Raval, T.S. O'Brien, P.H. Maxwell, Regulation of E-cadherin expression by VHL and hypoxiainducible factor, Cancer Res. (2006)https://doi.org/10.1158/0008-5472.CAN-052670.

[254] B. Krishnamachary, D. Zagzag, H. Nagasawa, K. Rainey, H. Okuyama, J.H. Baek, G.L. Semenza, Hypoxia-inducible Factor-1-dependent repression of E-cadherin in von Hippel-Lindau tumor suppressor-null renal cell carcinoma mediated by TCF3, ZFHX1A, and ZFHX1B, Cancer Res. 66 (2006) 2725-2731, https://doi.org/10.1158/ 0008-5472.CAN-05-3719.

[255] V. te Boekhorst, L. Jiang, M. Mahlen, M. Meerlo, G. Dunkel, F.C. Durst, Y. Yang, H. Levine, B.M.T. Burgering, P. Friedl, Calpain-2 regulates hypoxia/HIF-induced amoeboid reprogramming and metastasis, BioRxiv. (2020)https://doi.org/10.1101/2020. 01.06.892497.

[256] Y. Tabata, D. Yoshino, K. Funamoto, R. Koens, R.D. Kamm, K. Funamoto, Migration of vascular endothelial cells in monolayers under hypoxic exposure, Integr. Biol. (Camb). 11 (2019) 26-35, https://doi.org/10.1093/intbio/zyz002.

[257] I. Djagaeva, S. Doronkin, Hypoxia response pathway in border cell migration, Cell Adhes. Migr. 4 (2010) 391-395, https://doi.org/10.4161/cam.4.3.11790.

[258] K. Iwasaki, R. Ninomiya, T. Shin, T. Nomura, T. Kajiwara, N. Hijiya, M. Moriyama, H. Mimata, F. Hamada, Chronic hypoxia-induced slug promotes invasive behavior of prostate cancer cells by activating expression of ephrin-B1, Cancer Sci. 109 (2018) 3159-3170, https://doi.org/10.1111/cas.13754.

[259] E. Khain, M. Katakowski, S. Hopkins, A. Szalad, X. Zheng, F. Jiang, M. Chopp, Collec- 
tive behavior of brain tumor cells: the role of hypoxia, Phys. Rev. E - Stat. Nonlinear Soft Matter Phys. (2011)https://doi.org/10.1103/PhysRevE.83.031920.

[260] P. Friedl, K. Wolf, Plasticity of cell migration: a multiscale tuning model, J. Cell Biol. (2010)https://doi.org/10.1083/jcb.200909003.

[261] D. Pramanik, M.K. Jolly, R. Bhat, Interactive dynamics of reaction-diffusion and adhesion predict diverse invasion strategies of cancer cells in matrix-like microenvironments, BioRxiv. 041632 (2020)https://doi.org/10.1101/2020.04.14.041632.

[262] M.K. Jolly, M. Boareto, B.G. Debeb, N. Aceto, M.C. Farach-Carson, W.A. Woodward, H. Levine, Inflammatory breast cancer: a model for investigating cluster-based dissemination, NPJ Breast Cancer. 3 (2017) 21, https://doi.org/10.1101/119479.

[263] F.L.C. Faldoni, C.A. Rainho, S.R. Rogatto, Epigenetics in inflammatory breast cancer: biological features and therapeutic perspectives, Cells. 9 (2020) 1164, https://doi. org $/ 10.3390 /$ cells 9051164 .

[264] J.S. Tomlinson, M.L. Alpaugh, S.H. Barsky, An intact overexpressed E-cadherin/alpha, beta-catenin axis characterizes the lymphovascular emboli of inflammatory breast carcinoma, Cancer Res. 61 (2001) 5231-5241.

[265] X. Zheng, J.L. Carstens, J. Kim, M. Scheible, J. Kaye, H. Sugimoto, C.-C. Wu, V.S. LeBleu, R. Kalluri, Epithelial-to-mesenchymal transition is dispensable for metastasis but induces chemoresistance in pancreatic cancer, Nature. 527 (2015) 525-530, https://doi.org/10.1038/nature16064.

[266] M. Voglstaetter, A.R. Thomsen, J. Nouvel, A. Koch, P. Jank, E.G. Navarro, T. GaineySchleicher, R. Khanduri, A. Groß, F. Rossner, C. Blaue, C.M. Franz, M. Veil, G. Puetz, A. Hippe, J. Dindorf, J. Kashef, W. Thiele, B. Homey, C. Greco, C. Boucheix, A. Baur, T. Erbes, C.F. Waller, M. Follo, G. Hossein, C. Sers, J. Sleeman, I. Nazarenko, Tspan8 is expressed in breast cancer and regulates E-cadherin/catenin signalling and metastasis accompanied by increased circulating extracellular vesicles, J. Pathol. 248 (2019) 421-437, https://doi.org/10.1002/path.5281.
[267] X. Hu, E.S. Villodre, R. Larson, O.M. Rahal, X. Wang, Y. Gong, J. Song, S. Krishnamurthy, N.T. Ueno, D. Tripathy, W.A. Woodward, B.G. Debeb, Decorin, a novel negative modulator of E-cadherin in inflammatory breast cancer, BioRxiv. (2020)https://doi.org/10.1101/2020.07.07.190496 2020.07.07.190496.

[268] K. Chu, K.M. Boley, R. Moraes, S.H. Barsky, F. Robertson, The Paradox of E-Cadherin: role in response to hypoxia in the tumor microenvironment and regulation of energy metabolism, Oncotarget. 4 (2013) 446-462, https://doi.org/10.18632/oncotarget. 872.

[269] Y. Hao, D. Baker, P. Ten Dijke, TGF- $\beta$-mediated epithelial-mesenchymal transition and cancer metastasis, Int. J. Mol. Sci. (2019)https://doi.org/10.3390/ijms20112767.

[270] S. Giamperi, C. Manning, S. Hooper, L. Jones, C.S. Hill, E. Sahai, Localized and reversible TGFbeta signalling switches breast cancer cells from cohesive to single cell motility, Nat. Cell Biol. 11 (2009) 1287-1296.

[271] C. Rypens, M. Marsan, C. Van Berckelaer, C. Billiet, K. Melis, S.P. Lopez, P. van Dam, G.R. Devi, P. Finetti, N.T. Ueno, F. Bertucci, P. Dirix, P. Neven, P. Vermeulen, L. Dirix, S.J. Van Laere, Inflammatory breast cancer cells are characterized by abrogated TGFß1-dependent cell motility and SMAD3 activity, Breast Cancer Res. Treat. (2020) https://doi.org/10.1007/s10549-020-05571-z.

[272] P. Chaturvedi, D.M. Gilkes, N. Takano, G.L. Semenza, Hypoxia-inducible factordependent signaling between triple-negative breast cancer cells and mesenchymal stem cells promotes macrophage recruitment, Proc. Natl. Acad. Sci. U. S. A. (2014) https://doi.org/10.1073/pnas.1406655111.

[273] J.E. Park, B. Dutta, S.W. Tse, N. Gupta, C.F. Tan, J.K. Low, K.W. Yeoh, O.L. Kon, J.P. Tam, S.K. Sze, Hypoxia-induced tumor exosomes promote M2-like macrophage polarization of infiltrating myeloid cells and microRNA-mediated metabolic shift, Oncogene. (2019)https://doi.org/10.1038/s41388-019-0782-x 